Rhode Island College

Digital Commons @ RIC

$12-1-2019$

\title{
A Systematic Review Examining the Efficacy of Epidural Analgesia on Mortality in Older Adult Patients with Rib Fractures
}

Erin Casimiro

Follow this and additional works at: https://digitalcommons.ric.edu/etd

Part of the Nursing Commons

\section{Recommended Citation}

Casimiro, Erin, "A Systematic Review Examining the Efficacy of Epidural Analgesia on Mortality in Older Adult Patients with Rib Fractures" (2019). Master's Theses, Dissertations, Graduate Research and Major Papers Overview. 311.

https://digitalcommons.ric.edu/etd/311

This Major Paper is brought to you for free and open access by the Master's Theses, Dissertations, Graduate Research and Major Papers at Digital Commons @ RIC. It has been accepted for inclusion in Master's Theses, Dissertations, Graduate Research and Major Papers Overview by an authorized administrator of Digital Commons @ RIC. For more information, please contact digitalcommons@ric.edu. 



\section{A SYSTEMATIC REVIEW EXAMINING THE EFFICACY OF EPIDURAL ANALGESIA ON MORTALITY IN OLDER ADULT PATIENTS WITH RIB FRACTURES}

A Major Paper Presented

by

Erin Casimiro

Approved:

Committee Chairperson

Committee Members

(Date)

(Date)

(Date)

Director of Master's Program

(Date)

Dean, School of Nursing 


\title{
A SYSTEMATIC REVIEW EXAMINING THE EFFICACY OF EPIDURAL ANALGESIA ON MORTALITY IN OLDER ADULT PATIENTS WITH RIB FRACTURES
}

\section{Erin Casimiro}

\author{
A Major Paper Submitted in Partial Fulfillment \\ of the Requirements for the Degree of \\ Master of Science in Nursing \\ in
}

The School of Nursing

Rhode Island College

2019 


\begin{abstract}
Rib fractures are a common consequence of blunt force trauma, producing pain and potentially leading to complications such as pneumonia, atelectasis, respiratory failure, and death. Due to physiological changes related to aging, older adults aged 65 and over are at increased risk for developing such complications. Aggressive treatment of pain has been recognized as paramount in preventing such consequences. While there are multiple modalities to treat pain related to rib fractures, epidural analgesia has frequently been recognized as an effective means of preventing pulmonary complications and decreasing mortality in an opioid sparing technique. However, it remains unclear if this therapy would serve as a definitive treatment in the population of older adults. The purpose of this systematic review was to determine the effect of epidural analgesia on decreasing mortality in the older adult patient population. Literature and pertinent randomized controlled trials were searched for inclusion within this review. Six trials were included within this review utilizing the PRISMA checklist and CASP tool to extract and critically appraise data. Cross study analysis was then utilized to determine overarching themes within the data. This systematic review did not find any statistically significant data to suggest that mortality is decreased in older adults by utilizing epidural analgesia after thoracic trauma. Further research is necessary utilizing prospective data focusing on this particular patient population in order to better determine the effectiveness of this treatment.
\end{abstract}

Keywords: rib fractures, older adult, epidural analgesia, thoracic trauma 


\section{Table of Contents}

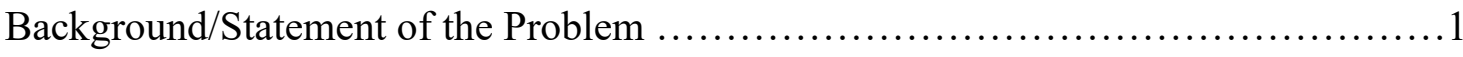

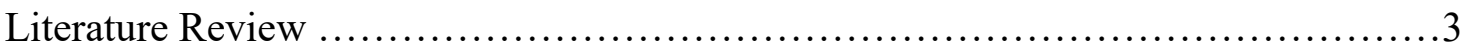

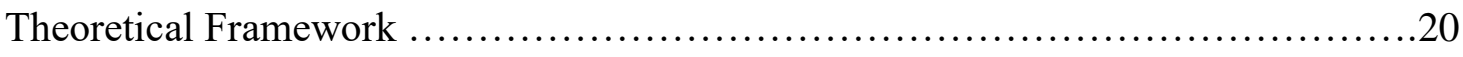

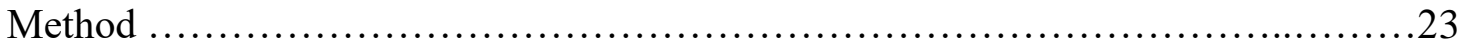

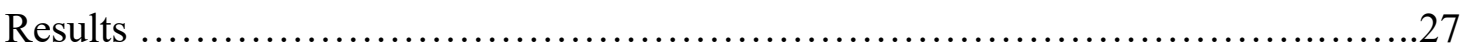

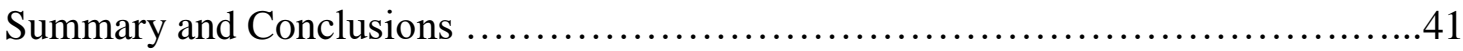

Recommendations and Implications for Advanced Nursing Practice ................45

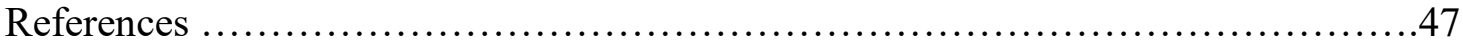

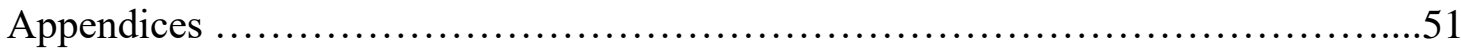


A Systematic Review Examining the Efficacy of Epidural Analgesia on Mortality in Older Adult Patients with Rib Fractures

\section{Background/Statement of the Problem}

Rib fractures are common among individuals who sustain blunt force trauma. Leininger (2017) reported that approximately 10\% of elderly individuals (aged 65 and over) who experience blunt trauma sustain at least one rib fracture. These injuries cause a great deal of pain and discomfort. With this discomfort, an individual is placed at higher risk for pulmonary complications such as atelectasis, pneumonia and respiratory failure. These risks are even more significant for the older adult population, specifically patients aged 65 and older. As individuals age, normal physiologic changes affecting the structure and function of the body occur (Leininger, 2017). These changes cause a weakening of the bones and muscles in the thoracic cage, placing older patients who sustain rib fractures at a higher likelihood to develop pulmonary complications, and an increased risk for injury related mortality (Leininger, 2017). Winters (2009) conveyed that rib fracture associated mortality increases about 5\% with every year over the age 65. Treating pain is of utmost importance in attempting to decrease the development of complications related to chest trauma.

There are several ways of approaching pain management when treating an older adult patient with rib fractures. Each approach may have varying benefits as well as side effects. These methods may include non-opioid and opioid based oral medications as well as intravenous narcotic medications. Of highlighted importance is the use of epidural analgesia. This may be done independently as treatment or in conjunction with the previous two methods mentioned. There are specific criteria that a patient must meet to 
have an epidural catheter placed, and those who sustain chest trauma may also have experienced additional injuries preventing its use. However, when appropriate epidural analgesia can provide effective pain relief without the side effects that intravenous medications can produce, such as sedation and respiratory depression. The side effects produced by some oral and intravenous medications can increase the likelihood of pulmonary complications if the patient is unable to participate in respiratory therapies and daily care activities. The purpose of this project is to conduct a systematic review to determine the effectiveness of epidural analgesia on mortality in older adult patients with rib fractures.

Next, a review of the literature will be presented. 


\section{Literature Review}

To begin reviewing the effects of epidural analgesia on the mortality of older adult patients with rib fractures, several aspects of this topic were investigated. A literature review was conducted utilizing Cinahl, Medline, Ovid, and PubMed. Search terms included "epidural analgesia," "rib fractures," "rib fracture complications," "elderly patients with rib fractures," as well as "treating chest trauma." These databases and search terms garnered appropriate results which will be appraised.

\section{Older Adult Patients}

As defined by Nagelhout and Plaus (2014), an "older adult" patient is defined as an adult over the age of 65 years. Other terms frequently associated with older adult may include, but are not limited to, "elderly" and "geriatric." For the purposes of this systematic review, the term used for the target population will be contained to "older adult." Due to improvements in both health care and overall living conditions, this population of individuals over the age of 65 has increased by $300 \%$ over the past 50 years, with further projected increase over the next decade (Nagelhout \& Plaus, 2014). Though not necessarily synonymous with poor health, aging includes fairly predictable physiologic changes. Nagelhout and Plaus (2014) state that age is not a reliable indicator of morbidity and mortality. Variable functional status remains throughout the population of older adults, though it is generally considered that this demographic is at a decreased ability to maintain or return to homeostasis when faced with disease, trauma, or surgical stressors (Nagelhout \& Plaus, 2014). 
While physiologic changes of aging occur throughout all body systems, of interest to this systematic review are those changes involving the respiratory system. Calcifications of the chest wall, intervertebral, and intercostal joints in conjunction with decreased intercostal muscle mass lead to decreased chest wall compliance (Nagelhout \& Plaus, 2014). Also contributing to decreased chest wall compliance is a flattening of the diaphragm and decrease in intervertebral disc height. Decreasing elasticity of lung tissue leads to a reduction in alveolar surface area available for gas exchange. This decrease in compliance paired with decreased elasticity leads to ventilation and perfusion mismatch, hindering oxygen exchange at the alveoli (Nagelhout \& Plaus, 2014).

Additional changes that occur with aging include: a decrease in vital capacity, an increase in residual volume, and a decrease in functional residual capacity. While overall total lung capacity usually remains unchanged, older adults exhibit impaired efficiency in their respiratory gas exchange (Nagelhout \& Plaus, 2014). Age related decreases in muscle mass contribute to the increased risk of respiratory failure and aspiration that many older adults face. Additionally, these changes can cause an increased work of breathing and decreased ability to maintain protective airway reflexes (Nagelhout $\&$ Plaus, 2014).

\section{Traumatic Rib Fractures}

As reported by Abdulrahman, et al. (2013), injury to the chest is reported in upwards of $50 \%$ of multi-trauma patients and is responsible for an estimated $25 \%$ of trauma associated mortality. Approximately two-thirds of these chest wall injuries include rib fractures, making them one of the most common chest injuries to be 
encountered. These injuries are most often sustained through falls and motor vehicle accidents (Sahr, Webb, Renner, Sokol, \& Swegle, 2013).

Rib fractures are complex injuries, and may be indicators of further damage, such as intrathoracic, abdominal, or skeletal injury (Abdulrahman, et al., 2013). Additionally, the number of fractured ribs may have different implications regarding morbidity and mortality, particularly as patients age. As documented by Sahr et al (2013), mortality rates related to rib fracture injuries double from $9 \%$ to $18 \%$ after the age of 65 . This insight has led to increased focus on appropriately treating patients who sustain traumatic rib fractures.

\section{Rib Fractures in the Older Adult Patient}

With an increase in the older adult population, the number of patients in this demographic group who experience trauma is also increased (Bulger, Arneson, Mock, \& Jurkovich, 2000). Hence, the need to identify how to best care for older adults who experience trauma. Due to age related changes, the bones and support muscles of the rib cage become weaker over time (Leininger, 2017). When a rib is fractured, the pain associated with this injury can make taking deep breathes an excruciating task. Even over a short period of time, this impaired breathing can lead to atelectasis, which may then lead to complications such as pneumonia and respiratory failure (Leininger, 2017).

Stawicki, Grossman, Hoey, Miller, and Reed (2004) sought to examine the relationship between number of rib fractures and mortality as patient age increases. The article, published in the Journal of the American Geriatric Society in 2004, detailed a retrospective study utilizing patient data obtained from the Pennsylvania Trauma System 
Foundation (Stawicki, et. al, 2004). Of the 27,855 patients identified, 8,648 were older adults; all patients were admitted to a Pennsylvania Trauma Center with at least one fractured rib. For this study, an older adult patient was defined as a person greater than 65 years of age.

Researchers found that overall mortality for older adult patients with rib fractures was greater than that of younger patients with similar chest trauma. Limiting this result may be the lack of information regarding circumstances of mortality such as living wills and advanced directives (Stawicki et al., 2004). Additionally, this patient population suffered more frequently from complications such as pneumonia and respiratory failure, whereas younger patients were more likely to experience atelectasis. Older patients were also found to have increased length of hospital and ICU stay, which shows that resource utilization after chest trauma is higher in this population as opposed to others. While this study showed correlation between rib fractures in older adults and increased mortality, it did not investigate any correlation on specific types of treatment and their effects on patient outcomes.

\section{Pulmonary Complications Associated with Rib Fractures}

Winters (2009) reported that pneumonia was the most serious and likely complication associated with rib fractures. Older individuals are four times more likely to die from this complication than those who do not develop pneumonia. This data supports Bulger, Arneson, Mock, and Jurkovich's (2000) research that states older adults with rib fractures are more likely to develop pneumonia, pulmonary effusions, acute respiratory 
distress syndrome (ARDS), lobar collapse, and empyema when compared to patients younger than 65 years old.

As described by Lively (2012), compression of bony and cartilaginous chest structures can result in tearing of underlying lung tissue, causing a pulmonary contusion. This injury, which is often associated with rib fractures, may trigger an inflammatory response leading to alveolar edema, surfactant dysfunction, and decreased lung compliance (Lively, 2012). From these contusions, the complication of pneumonia may develop due to decreased bacterial clearance in the contused lung (Lively, 2012).

\section{Defining Acute Pain}

Carr and Goudas (1999) define acute pain as "the normal, predicted physiological response to an adverse chemical, thermal, or mechanical stimulus...associated with surgery, trauma and acute illness" (p. 2051). Nociceptive pain detects, localizes, and serves to limit tissue damage (Butterworth, Mackey, \& Wasnick, 2013). Nociceptors, which are free nerve endings found in skin, muscle, bone, and connective tissue, contain cell bodies which are located in the dorsal root ganglia of spinal nerve roots (Barash, Cullen, Stoelting, Cahalan, \& Stock, 2009). First-order neurons make up a dual ascending afferent pathway, with peripheral origins as A-delta and C fibers. A-delta fibers are known to transmit "first" or "fast" pain, which is well localized and described as sharp in nature. Barash et al. (2009), goes on to describe polymodal C fibers as transmitters of "second" or "slow" pain, which is more diffuse and associated with burning pain which may be more chronic in nature. These first-order neurons synapse onto second-order neurons within the dorsal horn laminas I, II, V, where they release excitatory amino acids 
and neuropeptides (Barash et al., 2009). Second-order neurons are either nociceptivespecific or wide dynamic-range (WDR) neurons, which ascend the spinal cord via the dorsal column and anterior lateral spinothalamic tract to synapse on third-order neurons in the contralateral thalamus. There, input is further projected to the somatosensory cortex where nociceptive input is perceived as pain (Barash et al., 2009).

As detailed by Barash et al. (2009), pain is processed in four stages: transduction, transmission, modulation, and perception. Transduction occurs when a noxious stimuli is converted into an action potential. Transmission is the process of the action potential being conducted through the nervous system via first, second, and third-order neurons. Modulation involves the alteration of afferent neural transmission along the pain pathway within the dorsal horn of the spinal column, involving either inhibition or augmentation of the pain signal. Finally, perception of pain results from the integration of painful afferents into the somatosensory and limbic cortices (Barash et al., 2009). Traditionally, analgesic therapy has aimed to modulate one's perception of pain, while multimodal approaches to pain management attempt to target all four phases of pain processing.

Two types of acute pain are described by Butterworth et al. (2013): somatic and visceral acute pain. Superficial somatic pain arises from nociceptive input at level of the skin, subcutaneous tissues, or mucous membranes. It is typically well localized and described as sharp or throbbing. Deep somatic pain is derived from muscles, tendons, joints, or bones and typically is less well localized and described as dull and aching in quality. Visceral pain is related to disease or abnormality of an internal organ or its covering. Embryological development and migration of tissues accounts for the often times referred description of visceral pain to other parts of the body (Butterworth et al., 
2013). The presence of rib fractures may be best described as deep somatic pain but may also involve superficial somatic pain in the presence of additional trauma. Most acute pain is self-limiting in nature, resolving with treatment. However, acute pain may potentially become chronic if it persists for greater than six months.

\section{Acute Pain Assessment for the Older Adult}

Herr and Garand (2001) approached the specificities necessary to adequately assess pain in the older adult. They focused first on misconceptions surrounding this patient population, such as that pain is an expected consequence of aging, or that older adults experience less pain than their younger counterparts (Herr \& Garand, 2001). The authors recognize that older adults often expect pain with aging, or fail to report or underreport pain in an effort to prevent being seen as a nuisance to staff. Older adults may also be fearful of reporting pain, believing it may be due to severe pathology, impending death, or need for hospitalization or loss of independence.

Herr and Garand (2001) detail that accurate and aggressive assessment of pain is necessary for this population. An accurate clinical assessment for acute pain may uncover the underlying cause of such pain, which may then be remedied. The authors state that across all age groups, patient self-report is the most precise and reliable assessment for both the presence of pain as well as its quality (Herr \& Garand, 2001). They describe that older adult patients may use different terminology for their pain, discussing it in related terms such as "soreness," or "aching." An individualized approach to choosing a pain scale or tool should be taken, especially in the presence of cognitive dysfunction such as in the presence of Parkinson's disease or dementia. Furthermore, the healthcare provider 
should allow time for the older adult patient to process the question asked regarding pain, as well as time to develop their response.

The numeric rating scale (NRS) is the most frequently utilized self-reporting tools for assessing pain intensity. This scale involves asking the patient to rate their pain from 0-10, with 0 representing "no pain" and 10 representing the extreme of the patient's pain tolerance. Herr and Garand (2001) suggest that a vertically oriented visual representation of this scale may be easier for patients with alterations in abstract thinking to understand and utilize. The verbal descriptor scale (VDS) includes a series of phrases that represent different levels of pain; examples include, "no pain," "moderate pain," and "severe pain." While it is best utilized in patients who are more articulate without cognitive disruption, the VDS is the preferred pain scale for many older adults as described by Herr and Garand (2001). Pictorial pain scales, such as the Wong-Baker Faces Pain Scale, utilize faces representing different severity levels of pain. Herr and Garand (2001) detail that these scales are reliable for older adults with mild to moderate cognitive impairment.

While there are numerous tools for assessing pain intensity in older adults, Herr and Garand (2001) recognize that the most preferred by this patient population are the NRS and VDS. However it is assessed, pain must be vigilantly assessed by all members of the healthcare team through both verbal self-reporting tools as well as observation. A multidisciplinary approach should be taken to adequately control pain and prevent loss of function or further injury in this patient population.

The Royal College of Physicians, in partnership with the British Geriatrics Society and British Pain Society have recognized the need for pain assessment 
recommendations specific to the older adult patient. In 2007, they published national guidelines for the assessment of pain in older people, citing that while pain is a universal condition experienced by all, it is difficult for some individuals to articulate this experience. Pain is a subjective experience, which is often under recognized (and therefore under-treated) in older adults (Royal College of Physicians, 2007). Through their review, the Royal College of Physicians (2007) recommend that older people with no significant cognitive or communication impairment be assessed for pain utilizing selfreport, numeric graphic rating scales, or verbal numeric rating scales. With cognitive or communication impairment, it is recommended to utilize more observational pain assessment tools and multidimensional assessments. The latter tools utilize observation of facial expression, changes in body language and behavior, as well as physiologic change such as changes in blood pressure, heart rate, and skin pallor or flushing. In summary, the Royal College of Physicians emphasized that all healthcare professionals should be aware of the possibility of pain in older adults, and of the fact that they are often reluctant to acknowledge and report such pain.

Barash et al. (2009), describe that the most effective way to begin assessing a patient for pain is to ask, and fully listen to the answers given. Assessment by the CRNA should be multidimensional, relying on open-ended questions, traditional pain assessment tools, and keen observation of patient behavior and physiologic status.

\section{Pain Management for Older Adults}

A major complication associated with traumatic injury, including rib fractures, is pain. The assessment and management of pain is paramount to the patient's healing, 
which includes rigorous breathing exercises to prevent pulmonary complications such as pneumonia. Karmakar et al. (2003) conducted a non-randomized prospective study, regarding the effectiveness of paravertebral infusions for pain management related to multiple rib fractures. A paravertebral infusion involves unilateral dermatomal anesthesia, by injecting local anesthetic into the paravertebral space. This space is defined as small wedge-shaped area located on either side of the vertebral column which contains bundled spinal nerves (New York School of Regional Anesthesia [NYSORA], 2018).

Fifteen adult patient, ages ranging 23 to 89 years, were enrolled in the study, with a mean age of 52.8 years old (Karmakar, et al., 2003). Included were patients that had sustained three or more unilateral rib fractures. A continuous paravertebral infusion of bupivacaine $0.25 \%$ was utilized for four days, with outcome criteria of pain scores, respiratory status, and incentive spirometry. During the time in which the infusion was utilized, results showed that no other opioids were required for these patients, with pain being reported as well controlled. There was an improvement of respiratory function as well throughout the course of the study. These results, however, are limited. With only fifteen participants and no control group, this observational study appears to show a positive correlation in terms of pain management with paravertebral analgesia, but not strong enough to necessarily promote a change in practice without repeated research. Additionally, it may be difficult to apply these results to the older adult population, as the mean age of this cohort was just 52.8 (Karmakar, et al., 2003).

An accurate pain assessment is an integral step in adequately treating the discomfort associated with chest trauma. Cognitively intact individuals can generally utilize a self-reporting tool such as the Numeric Rating Scale (Winters, 2009). In the 
older adult population, patients may describe pain differently or may underreport pain. If a patient is not cognitively intact, such as in the case of dementia, they may have difficulty expressing their pain. In this case, it is recommended that an analgesic trial is utilized (Winters, 2009). An analgesic trial is described by Winters (2009) as administering pain medication and assessing any changes in perceived levels of patient comfort. This method of measurement may not be accurate and may not be conducive to standardization among all patients. According to clinical guidelines developed by Winters (2009), it may be more appropriate to measure vital capacity through use of an incentive spirometer to assess if pain management is adequate when being hospitalized for rib fractures. Those with vital capacity less than 1.4 liters have been shown to have an increased hospital stay greater than three days (Winters, 2009).

Typically, there are many different modalities utilized in treating the pain associated with ribs fractures in the older adult population. Non-opioid as well as opioid medications may be given. Examples may be acetaminophen for mild pain, with an opioid analgesic such as oxycodone for moderate to severe pain (Winters, 2009). For patients who are unable to take parenteral medications, intravenous medications such as morphine, fentanyl, or hydromorphone may be effective. However, due to the sedative effects of these medications as well as the potential for respiratory depression, IV opioids should be used in the smallest effective dose to prevent complications such as decreased respiratory drive and participation in pulmonary exercise such as incentive spirometry. In the guidelines presented by Winters (2009), the use of epidural and paravertebral analgesia is described as an effective method for pain management for those patients who do not have contraindications to its usage. Epidural and paravertebral analgesia may be 
used alone, or in conjunction with non-opioid and/or opioid analgesics. Paravertebral analgesia provides effective pain relief for patients whom an epidural is a contraindication (Winters, 2009).

\section{Treating Rib Fractures with Continuous Epidural Analgesia}

In addition to parenteral opioid and non-opioid medications to treat pain, the use of epidural analgesia may also be implemented. The use of epidural analgesia may be used alone, or as an adjunct to previously described therapies. For this therapy, a catheter is inserted into the epidural space, at which point medication is infused. Typically, this may consist of bupivacaine as well as an added low-dose narcotic such as hydromorphone, fentanyl, or morphine.

In a study by Bulger, et. al (2000), a retrospective cohort study was done, evaluating 277 patients over the age of 65 . All patients had been admitted to the same Level 1 Trauma Center during a ten-year period, and were compared against a control group of 187 randomly selected patients with similar injuries between the ages of 18 and 64. In this quantitative study, the purpose was to determine if there was correlation between age and increased morbidity and mortality after sustaining rib fractures. Researchers quantified pulmonary complications (respiratory failure, pneumonia, pulmonary effusion), length of stay, number of days spent on a ventilator (if the patient were intubated during admission), and mortality (Bulger, et al., 2000). It was found that the older adult population examined experienced a greater incidence of pulmonary complications, as well as increased mortality. It should also be noted that researchers found that these outcomes increased as the number of ribs fractured increased (Bulger, et 
al., 2000). Patients in this study who had three to four rib fractures had $19 \%$ mortality, while those with greater than six rib fractures had 33\% mortality (Bulger, et al., 2000). While it was not examined in this research, Bulger et. al did recognize that worsening outcomes for this age group may be related to pre-existing comorbidities and decreased physiologic reserve.

Bulger, et al. (2000) went on to examine the usage of epidural analgesia. Older adult patients who sustained rib fractures were more likely to receive epidural analgesia at a rate of $22 \%$ to $15 \%$ in the younger cohort. Mortality for this older group of patients was decreased; 7 of 62 patients who received epidural management expired, versus 54 of 215 patients who did not receive an epidural. Though mortality rates were lower, Bulger, et al. (2000) found that patients who received continuous epidural analgesia to manage their rib fracture pain had increased pulmonary complication rates as well as increased ICU and hospital length of stay. It should be noted that a limitation of this result may be an increase in injury severity in conjunction with epidural therapies, therefore an expected rise in length of stay. Researchers reported that regardless of specific treatment, older patients who sustain acute rib fractures should be aggressively managed with appropriate respiratory care and pain management to decrease risk of complications and mortality (Bulger, et al., 2000).

Gage et al. (2013) also sought to examine the efficacy of using continuous epidural analgesia infusions for patients with blunt chest trauma, particularly greater than three rib fractures. Since epidural analgesia has fewer sedating effects than intravenous or parenteral narcotics, patients are better able to participate in therapies such as respiratory treatments and early mobility, which may lead to improved outcomes. Researchers 
utilized a retrospective cohort study examining patients aged 18 to 84 at 69 participating hospitals in the United States (Gage, et al., 2013). Of these participating hospitals, 18 were Level 1 Trauma Centers, with 51 being non-trauma centers. Utilizing the National Study on Cost and Outcomes of Trauma Database, Gage, et al (2013) found 5043 patients who had sustained chest trauma, 100 of which received epidural analgesia. Researchers hypothesized that the use of epidural analgesia would decrease short- and long-term mortality. Primary exposure for this study was the placement of an epidural, with primary outcomes being death in hospital, and within 30, 90, and 365 days from time of injury (Gage, et al., 2013).

Patients with a greater number of rib fractures were more likely to receive continuous epidural infusion, with $52.1 \%$ of patients with eight or more rib fractures receiving this treatment. Of those with six or seven rib fractures, only $5.2 \%$ of patients received epidurals. This low percentage may be due to outside factors such as the patients not being treated at a Level 1 Trauma Center, or comorbidities contraindicating the usage of epidurals. For patients with three to five and zero to two rib fractures, the percentages of epidurals placed were $29.6 \%$ and $13 \%$ respectively (Gage, et al., 2013). Patients who were older, mean age 50.9 years, were more likely to have an epidural placed. However, the mean age of those who did not receive epidural analgesia was not meaningfully lower, at 44.2 years.

This study found that patients who received epidural analgesia had a significantly decreased mortality at all time points that were examined. Adjusted odds of death were as follows: 30 days, 0.08, 90 days 0.09 , and 365 days 0.12 all of which demonstrated a confidence interval of $95 \%$ (Gage, et al., 2013). While mortality decreased, lengths of 
stay in the intensive care unit as well as the hospital increased for patients receiving this type of pain management, but were less likely to be discharged to a skilled nursing facility. There may be limitations to this result, as the increased length of stay may be related to severity of injury, or improved mortality secondary to ICU level of care and increased level of observation contributing to improved outcomes. Another limitation to this study may be that $85 \%$ of epidural catheters in this research were placed at Level 1 Trauma Centers. This is suggestive that improved outcomes simply demonstrate triage and treatment received at these types of facilities. Gage, et al. (2013) did recognize this bias, and pulled data from this cohort, showing that while looking at only data produced from Level 1 Trauma Centers, mortality still improved with the use of epidural analgesia as opposed to traditional treatment. Researchers in this study concluded that this approach may be beneficial in that it allows for decreased opioid administration and provides more non-sedating relief which can decrease the incidence of hospital induced delirium, as well as allow for greater participation in therapies.

Contraindications to epidural use. The major contraindications for epidural anesthesia include: patient refusal, bleeding diathesis, severe hypovolemia, elevated intracranial pressure, and infection at the site of injection (Butterworth et al., 2013). Relative contraindications include severe aortic or mitral stenosis and severe left ventricular outflow obstruction. Additionally, relative contraindications include: sepsis, uncooperative patients, preexisting neurological deficit, and severe spinal deformities.

It should also be noted that the presence of anticoagulant or antiplatelet medications play a role in the decision to utilize epidural anesthesia and analgesia. As the population of patients that take such agents gets larger with advanced age, it is sensible to 
be aware of the considerations involved with these drugs. The American Society of Regional Anesthesia and Pain Medicine (ASRA) has issued guidelines regarding the use of neuraxial anesthesia in the presence of antiplatelet and anticoagulant therapy, as to prevent the devastating complication of epidural hematoma. As described by Butterworth et al. (2013), patient on oral anticoagulants such as warfarin should have a documented normal PT/INR prior to receiving epidural analgesia. Aspirin and other NSAIDs alone do not increase the risk for epidural hematoma, but more potent antiplatelet medications have documented waiting periods that should be adhered to prior to epidural catheter insertion. For example, patients on clopidogrel (Plavix) should have a 7-day waiting period (Horlocker, Vandermeuelen, Kopp, Gogarten, Leffert, ...\& Benzon, 2018). The development of oral factor Xa inhibitors has provided relative complications with determining guidelines for waiting periods and potential reversal. As these agents and their reversals are still relatively new, Horlocker et al. (2018) suggest that further clinical experience be necessary prior to issuing guidelines for practice.

While there are many approaches to pain management for the older adult patient who has sustained fractured ribs, the efficacy of utilizing epidural analgesia remains contentious. There are several contraindications to its usage, including coagulopathies, severe head injury, and spinal fractures; these may all be present in the aging patient population. However, epidural analgesia may provide appropriate, non-sedative pain relief, which can improve the ability for patients to maintain mobility as well as ability to participate in necessary respiratory therapies. The lack of definitive research on whether epidural analgesics decrease mortality for this patient population leads to more questions regarding its usage and potential benefits as a frequently utilized treatment. 
Next, a theoretical framework will be detailed. 


\section{Theoretical Framework}

In an ever-changing healthcare environment, systematic reviews and metaanalyses have gained increasing importance in the development of clinical practice guidelines. To accurately utilize these comprehensive studies, they must be rigorous in terms of methods, evidence, and transparency. As described by Liberati et al. (2009), this transparency allows readers to fully assess the strengths and weaknesses of the systematic review or meta-analysis being reported. In order to do this, the PRISMA (Preferred Reporting Items for Systematic Reviews and Meta-Analyses) statement has been developed as a utilization tool to ensure accuracy in reporting.

Moher, Liberati, Tetzlaff, Altman, and the PRISMA Group (2009) reported on the development of the PRISMA statement. Developed in 2005 over the course of three days, 29 participants, including clinicians, methodologist, review authors, and medical editors sought to revise the previously utilized QUOROM (Quality of Reporting of MetaAnalyses) statement (Moher et al., 2009). The QUOROM statement was published in 1999 as the original guidance in reporting for authors of meta-analyses and systematic reviews but was determined to not be the ideal form of reporting (Liberati et al., 2009). From the 2005 revision, a 27 -item checklist was developed and published in 2009, aiming to improve the reporting of both systematic reviews and meta-analyses (Moher et al., 2009). This checklist is illustrated in Appendix A. The PRISMA checklist differs from the QUOROM statement in that it aims to improve consistency among reports.

The PRISMA statement includes a four-phase flow diagram which documents the flow of information through the phases of a systematic review. This diagram (illustrated in Figure 1) tracks the number of records identified through to the included studies in the 
systematic review or meta-analysis which meet inclusion criteria (Moher et al., 2009).

The diagram presents visual evidence of a rigorous literature search as well as screening for eligibility criteria throughout all phases of the systematic review process. It also ensures consistency in rigor among performed systematic reviews and meta-analyses.

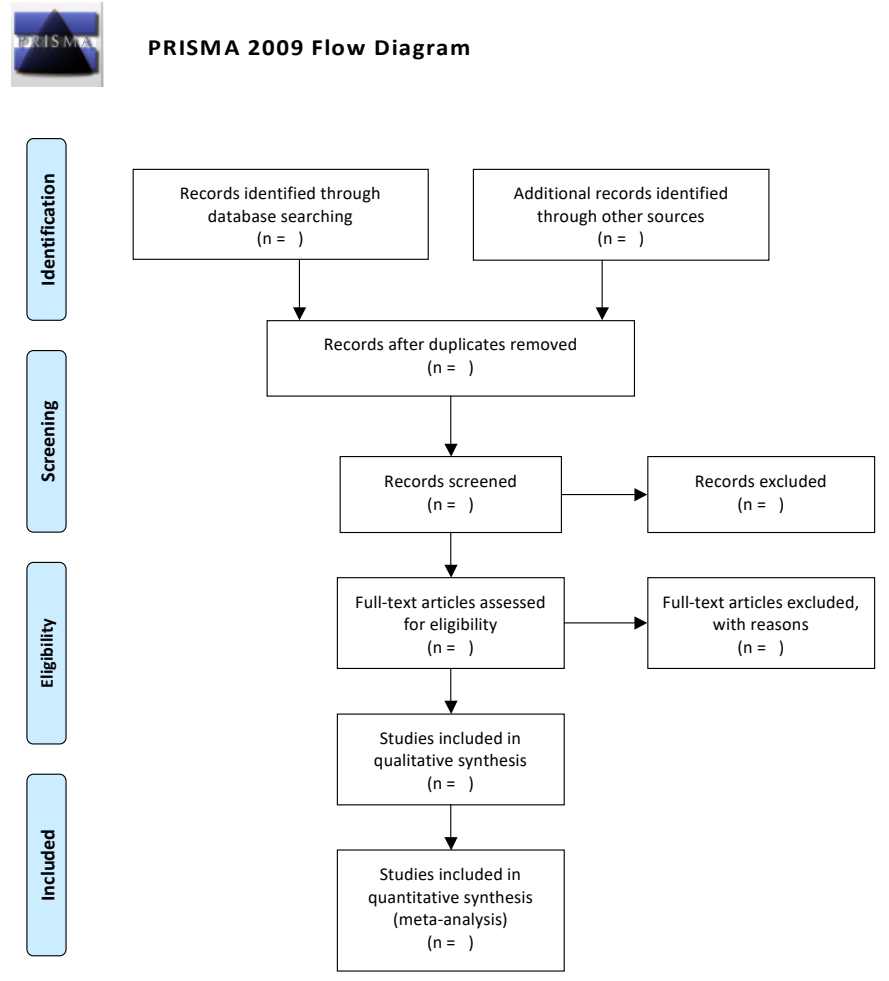

Figure 1. PRISMA Flow Diagram (Moher et al., 2009)

Due to the importance of transparency and lack of bias in conducting systematic reviews, the PRISMA statement is highly endorsed among researchers as the preferred method of reporting these types of studies (Moher et al., 2009). For this reason, the 
PRISMA statement was utilized throughout this systematic review, with the purpose of determining the effectiveness of epidural analgesia in decreasing the mortality of elderly patients with rib fractures.

Next, the methodology for this systematic review will be detailed. 


\section{Method}

\section{Purpose / Outcomes}

The purpose of this project was to conduct a systematic review to determine the effectiveness of epidural analgesia in decreasing the mortality of older adult patients with rib fractures. Outcomes examined include effects of epidural analgesia on pulmonary complications such as pneumonia and respiratory failure, as well as mortality rates within 30 days. Through the results of this study, data was synthesized to determine how this patient population can be more effectively cared for after blunt thoracic trauma.

\section{Search Strategy}

An extensive literature review was conducted utilizing Medline, PubMed, Ovid, and the Cochrane Collaborative. The search for applicable literature aimed to locate all possible primary studies relating to the use of epidural analgesia for older adult patients with rib fractures. Due to the specific population being studied, secondary studies have also been reviewed to locate suitable data. Literature has been chosen appropriately based on this study's PICO question- population, intervention, comparison, and outcome (Polit $\&$ Beck, 2017). The population is older adult patients over 65 years old who have sustained rib fractures, with an intervention of epidural analgesia. Its comparison is standard treatment with parenteral and/or intravenous medication with an outcome of decreased mortality.

\section{Eligibility Criteria}

Inclusion Criteria. Regarding the specific population being studied, research examining cohorts of all adult patients in terms of age groups was utilized. Information and data considering those aged 65 and over was taken from randomized controlled trials 
found and utilized towards this systematic review. The patients examined had sustained one or more acute rib fracture and were treated with continuous epidural analgesia. Studies included documented rates of pulmonary complications including pneumonia and respiratory failure, as well as mortality rates.

Exclusion Criteria. Studies that did not examine rates of pulmonary complications and mortality were excluded from this systematic review. Patients treated with paravertebral blocks for pain management were excluded as well. Any studies published in a non-English language were excluded from this systematic review.

\section{Data Collection}

From each study utilized, the number of rib fractures sustained were surveyed, as well as specific age of the patients. The rates of epidural placement were compared within this research, and examined against accompanying rates of pulmonary complications and mortality. It should be noted that when examining pulmonary complications, studies included noted these as atelectasis, pneumonia, and respiratory failure. For this study, mortality was limited to death in the hospital.

\section{Table 1:}

\begin{tabular}{|l|l|l|l|l|l|l|l|}
\hline Purpose & $\begin{array}{l}\text { Study } \\
\text { Design }\end{array}$ & Sample & Intervention & Comparison & Outcomes & Findings & Limitations \\
\hline & & & & & & & \\
\hline
\end{tabular}




\section{Critical Appraisal and Cross Study Analysis}

The Critical Appraisal Skills Programme (CASP) offers guidelines and checklists that are to be utilized in the analysis of data for this systematic review. The CASP was originally developed in 1993, with the core checklists for RCTs and systematic reviews being developed in 1994 based on JAMA user's guides to medical literature (“CASP History," 2017). The checklists provided by CASP (2017) provide the ability to appraise evidence found in a systematic way, looking at the validity and consistency of research. CASP (2017) offers an 11 question checklist for randomized controlled trials which address three broad issues for appraisal: validity of study results, results of the study, and how results will help locally. This appraisal tool (found in Appendix B) was used for this systematic review to appropriately analyze data found within the research.

After being critically appraised, the data was summarized within each study as well as a whole. Data was synthesized to document any correlation between treatment with epidural analgesia and decreased pulmonary complications and mortality. Because different studies render different results, data was synthesized alone as well as across studies. Cross-study analysis was conducted in order to determine any overarching themes throughout the research. Particular attention was paid to trends in epidural usage and effects on mortality and the usage of epidural analgesia within particular patient populations, specifically older adults and patients with multiple rib fractures. Compilation of data through cross-study analysis was critical to this systematic review, as it allowed the proposed problem statement to be answered. 
Table 2: Cross-study Analysis Table.

\begin{tabular}{|l|l|l|l|l|}
\hline Author, Year & $\begin{array}{l}\text { Average Age of } \\
\text { Population }\end{array}$ & $\begin{array}{l}\text { Epidural - effect } \\
\text { on pneumonia } \\
\text { rates }\end{array}$ & $\begin{array}{l}\text { Epidural - } \\
\text { effect on } \\
\text { respiratory } \\
\text { failure }\end{array}$ & $\begin{array}{l}\text { Epidural - } \\
\text { effect on } \\
\text { mortality rate }\end{array}$ \\
\hline & & & & \\
\hline
\end{tabular}

Next, the results of this systematic review will be presented. 


\section{Results}

Six studies met inclusion criteria for this systematic review. Appendix D briefly summarizes each study. The PRISMA flow diagram (Appendix C), as well as inclusion criteria previously detailed, aided in the selection of randomized controlled trials to utilize for this review. The PRISMA flow diagram depicts a graphic representation of studies identified, screened, and chosen for this systematic review.

The original search terms "epidural analgesia" yielded 3510 results. Removal of duplicate studies left 2457 results. Additional search terms were utilized, including: "rib fracture" and "blunt thoracic trauma", yielding 46 results for review. Abstracts were then screened for inclusion or exclusion in this systematic review. The six studies chosen for inclusion in this review were analyzed, with data extracted into tables found in Appendix D. Critical appraisal data collection tables (Appendix E) are included to evaluate the integrity of each included study. Finally, a cross study analysis table (Appendix F) was designed and included for comparison of results.

\section{Individual Study Results}

McKendy, et al. (2017) (Appendix D, Table 2) aimed to find the effect of epidural analgesia on in-hospital mortality and respiratory complication in patients with rib fractures. The nine year, prospective matched analysis study took place at a universityaffiliated Level 1 Trauma Center. Included patients had sustained at least one rib fracture after sustaining blunt trauma. Exclusion criteria from the study included: penetrating trauma, simultaneous traumatic brain injury, or those who underwent a thoracotomy or laparotomy. A total of 1360 patients met inclusion criteria for this study, with 329 being 
treated with epidural analgesia and the remaining 1031 not being treated with epidurals. The decision to be treated with epidural analgesia was made by the treating physician. These two groups then underwent coarsened exact matching (CEM) to allow for comparable evaluation and minimize confounding effects of individual variables. CEM in this study accounted for differences in age, sex, Injury Severity Score (ISS), number of rib fractures, flail segments, and bilateral rib fractures. After matching, both the epidural and non-epidural treatment groups contained 204 patients, with no statistical differences in baseline characteristics. The mean age of patients was 54.2 years old and the mean number of ribs fractured was 4.8 .

Primary outcomes examined by McKendy, et al. (2017) included respiratory complications and 30-day in-hospital mortality. In the matched cohort, 19\% $(p=0.009)$ of patients treated with epidural analgesia sustained respiratory complications including pneumonia, deep vein thrombosis or pulmonary embolism, and respiratory failure. Those not treated with epidural analgesia had a $10 \%$ rate of respiratory complications. Specifically, $9 \%$ of epidural group patients had complications of pneumonia versus $5 \%$ in the group not treated with epidural analgesia $(p=0.073)$. Thirty day mortality in the epidural group was $5 \%$ versus $2 \%$ in the non-treatment group $(p=0.159)$. The higher rate of respiratory complications in the epidural group may reflect a difference in baseline characteristics in unmatched cohorts. Patients who were treated with epidurals may have been older, sicker, had a higher number or more severe rib fractures. Matched analysis by McKendy, et al. (2017) showed that epidural analgesia was associated with increased respiratory complications particularly when patients were older than 65 years and had sustained greater than three rib fractures. 
Utilizing the CASP questionnaire to evaluate this study (Appendix E, Table 1), McKendy et al. (2017) clearly focused on an issue, with all participants being accounted for throughout the duration of the study. Assignment of patients to treatment groups was not randomized, nor were investigators blinded to treatment groups during the study. Aside from intervention, both groups were treated equally, and through matched analysis, both groups were similar at the start of the trial. The results of this study may be applied to adult patients who have sustained rib fractures. However, there are several limitations to this study by McKendy, et al. (2017). Lack of blinding and randomization present a major limitation in this study, with selection bias being a potential reason for the inability to prove more widespread results. While researchers attempted to account for confounding variables through matched analysis, there remained potential for variables to be present, such as comorbidities that may place patients at higher risk for death and complications (smoking, pulmonary disease, etc.). McKendy, et al. (2017) also cited inexperience of providers with epidural analgesia as a potential limitation in achieving higher level results. Researchers concluded that there was no clear benefit to the use of epidural analgesia when compared to standard treatment, and that further research and higher quality data is necessary.

Bulger, Edwards, Klotz, and Jurkovich (2004) (Appendix D, Table 2) sought to determine if epidural analgesia would decrease the duration of mechanical ventilation and the incidence of pneumonia after multiple rib fractures when compared to IV opioid analgesics. Through a single-center, prospective, randomized trial, patients over the age of 18 with 3 or more rib fractures were evaluated. Exclusion criteria included: acute spine fracture, pre-existing spinal deformity, severe traumatic brain injury, spinal cord injury, 
severely altered mental status, unstable pelvic fracture, open abdomen, ongoing cardiac instability or coagulopathy, active chest wall infection, and acute thoracic aortic transection. Also excluded were patients whose pain was manageable with oral opioids or anti-inflammatory medications. Of the 408 patients identified as eligible for this study, 282 were excluded, and 80 refused participation or could not be consented for enrollment; a total of 46 eligible patients were enrolled. After being consented for this study, patients were randomized into two groups: epidural analgesia or IV opioid analgesia. To prevent selection bias by the research nurse, randomization assignments were placed into sealed envelopes and shuffled by an individual independent of the study (Bulger et al., 2004). Envelopes were then numbered sequentially and then taken in order at the time of randomization. Group 1 received epidural analgesia with bupivacaine and either morphine or fentanyl. Group 2 received IV opioid analgesia with morphine, hydromorphone, or fentanyl; alert patients utilized patient-controlled analgesia pumps while those who could not participate in self-administration had medications administered by a nurse. All patients were managed by the Pain Relief Service, a division of the Department of Anesthesiology.

The primary outcome of this study by Bulger et al. (2004) included the development of nosocomial pneumonia within the first 28 days of treatment. Secondary outcomes included: duration of mechanical ventilation, length of stay in the ICU or hospital, and mortality. Of the 46 participants enrolled, 22 were randomized to the epidural group and 24 to the IV opioid group. The mean age of Group 1 was $49 \pm 18$ years, while the mean age of Group 2 was $46 \pm 16$ years $(p=0.55)$. Patients in Group 1 had an $18 \%$ unadjusted rate of pneumonia occurrence, with Group 2 having a 38\% 
occurrence $(p=0.15)$. Adjusted for differences in direct pulmonary injury, patients in Group 2 had a 6-fold increase in their risk for developing pneumonia within 28 days (95\% CI, $p=0.05)$. Patients in Group 1 spent less time mechanically ventilated; a mean of 7.6 days versus 9.1 days in Group 2 patients. No difference in mortality or duration of hospital/ICU stay was noted between the epidural and systemic opioid groups.

In evaluating the integrity of this study utilizing the CASP questionnaire (Appendix E, Table 2), it appears that Bulger et al. (2004) addressed a clearly focused issue in their randomized trial. All included patients were randomized, and groups were comparable for age, gender, and mean number of ribs fractured at the beginning of the trial. Aside from treatment intervention, both groups were treated equally during the study period. While treatment was randomized, healthcare and study personnel were not blinded to the actual course of treatment. The results of this study may be applied to adults who have sustained blunt chest trauma and rib fractures in the absence of severe spinal cord or head injury, as well as coagulopathies or cardiac dysfunction. These exclusionary criteria are just some of several limitations to this study by Bulger et al. (2004). The small number of included participants does not allow for statistical significance in the data rendered. Additionally, the inability to blind providers and patients to the treatment modality may have allowed for bias in terms of treatment modifications for the intervention employed during the study period. An example of this given by Bulger et al. (2004) is the potential for providers to be more aggressive in weaning mechanical ventilation in the presence of an epidural catheter, accounting for a shorter duration in mechanical ventilation for this group. Furthermore, this study allowed for patients to "cross-over" to the alternative treatment group in the event that the 
assigned treatment was failing. This allows for a potential limitation in results, though cross-over appeared equally between both treatment groups. Bulger, et al. (2004) determined that epidural analgesia improved outcomes for patients having sustained multiple rib fractures, though the use of this treatment modality is limited by associated injuries.

Moon et al. (1999) (Appendix D, Table 3) evaluated systemic versus epidural opioid administration for analgesia in patients having sustained thoracic trauma in a prospective, randomized trial. Specifically, they sought to investigate the effect of either treatment on analgesia, pulmonary function, urinary catecholamine levels, and plasma cytokine levels. This single-center, two year study evaluated all patients aged 18 to 60 years old for eligibility after sustaining thoracic trauma. Eligibility was defined as one or more of the following: three or more consecutive rib fractures, flail chest wall segment, pulmonary contusion, and sternal fracture. Exclusion criteria were: contraindications to epidural catheter placement (coagulopathies, infection at insertion site, sepsis, or hypovolemic shock), morbid obesity, spinal cord injury above T10 level, Glasgow Coma Score $($ GCS $)<15$, adrenal insufficiency, use of steroids within six months of injury, hemodynamic instability, immunodeficiency disease, pregnancy, inability to effectively communicate, or allergy to local anesthetics or opioids (Moon et al., 1999). Of the thirtyfour initially enrolled, twenty-four patients completed the study.

Patients were randomized into either the PCA group or continuous epidural analgesia (CEA) group. Those in the PCA group received a loading dose of IV morphine $0.1 \mathrm{mg} / \mathrm{kg}$, followed by patient-controlled bolus doses of $2 \mathrm{mg}$ with a lockout of 10 minutes. Those in the CEA group had thoracic epidural catheters placed by an 
anesthesiologist, and a continuous infusion of $0.25 \%$ bupivacaine and $0.005 \%$ morphine at a rate of 4-6 mL/hr. A member of the acute pain service followed patients in each group adjusted dosing accordingly to optimize pain relief and minimize side effects. Pain relief was assessed for both groups utilizing a standard rating scale of 0-10.

Patients in the epidural group experienced a significant reduction in pain scores with coughing within the first 24 hours of treatment when compared to the PCA group ( $p$ $<0.05)$. After 48 hours, there was no statistical difference realized between the two groups. Furthermore, by the third day of treatment, the epidural group's pain scores again were significantly lower than that of the PCA group $(p<0.05)$. Regarding respiratory function, the epidural group showed a significant increase in maximal inspiratory force by the third day of treatment versus a continuous decline in that of the PCA group $(p<$ 0.05). Tidal volumes were also greater in the CEA group by day $3-590 \mathrm{~mL}$ versus 327 $\mathrm{mL}$ in the PCA group. There were no statistically significant data comparing the groups for plasma cytokines and urinary catecholamines.

Utilizing the CASP questionnaire (Appendix E, Table 3) to evaluate the integrity of this study, it appears that Moon et al. (1999) address a clearly focused issue. Patients involved in the study were randomized, and both groups were similar at the start of the trial. Also, aside from experimental intervention the groups were treated equally throughout the study period. Patients, healthcare providers, and study personnel were not "blinded" to the experimental intervention being received by participants in the trial. Results of this study may apply to adults who have sustained severe thoracic trauma in the absence of contraindications to epidural anesthesia. The results of this trial are limited due to the small sample size, thus the significance of data cannot truly be ascertained. 
Exclusionary criteria to this study limits the ability to apply this data to a larger population. Moon et al. (1999) recommended further research be necessary to determine the effectiveness of CEA in treating severe thoracic trauma.

In a prospective study, Sakura, Saito, and Kosaka (1996) (Appendix D, Table 4) sought to determine if thoracic epidural anesthesia would result in impaired response to hypercapnia and hypoxia as compared to lumbar epidural anesthesia in elderly patients. Patients included for study were at least 65 years old, ASA class I or II, had no history of cardiopulmonary disease, and had not recently received medication. Two groups of eight patients were examined: Group 1 received lumbar epidural anesthesia prior to lower abdominal surgery while Group 2 received thoracic epidural anesthesia prior to upper abdominal surgery. Baseline respiratory studies were performed the day prior to the scheduled surgery, and then performed again after the epidural anesthetic was placed. Ventilatory measurements obtained in the study by Sakura et al (1996) included minute ventilation, tidal volume, respiratory frequency, and end-tidal carbon dioxide concentration.

Regarding resting ventilation, minute ventilation decreased by $6 \%$ in Group 1 (lumbar epidural) and 13\% in Group 2 (thoracic epidural) after epidural injection was completed $(p, 0.05)$. Tidal volume decreased significantly in Group 2 but did not change in Group $1(p<0.05)$. Respiratory frequency did not change between groups, nor did $\mathrm{PaO} 2$ or $\mathrm{PaCO} 2$ levels. After a hypercapnic stimulation test using rebreathing of exhaled carbon dioxide for approximately six minutes, Group 1 demonstrated a significant increase in $\mathrm{V}_{\mathrm{E}}{ }^{55}$, an index of ventilatory response to hypercapnia $(p<0.05)$. Conversely, Group 2 did not demonstrate a significant difference between the two sets of 
measurements. Results show that lumbar epidural stimulates ventilatory responses in elderly patients, while thoracic epidural anesthesia is not associated with statistically significant changes.

When evaluating the integrity of the study using the CASP questionnaire (Appendix E, Table 4), Sakura et al. (1996) focus on a clear issue. Both groups of patients were similar at the start of the trial, and aside from experimental intervention were treated equally throughout the course of the study. Personnel was not "blinded" to the treatment, nor were experimental groups randomized, which present clear limitations to this trial. The small size of this study make it difficult to determine if data is able to be applied to larger populations of patients. Additionally, Sakura et al. (1996) noted that patient anxiety in itself may have influenced obtained data. Participants did not receive premedication prior to epidural placement, and anxiety has the potential to influence and increase ventilatory drive. Researchers sought to minimize this limitation by performing pre-treatment measurements in an operating room to accustom patients to the circumstances. Sakura et al. (1996) concluded that neither lumbar nor thoracic epidural anesthesia impair ventilatory response to hypercapnia or hypoxia in elderly patients, and that these techniques appear safe for patients with normal cardiopulmonary function.

To further investigate the use of epidurals in the older adult patient, a prospective randomized study by Mann et al. (2000) (Appendix D, Table 5) was appraised. Researchers sought to investigate the effectiveness of patient-controlled epidural analgesia (PCEA) and patient-controlled intravenous analgesia (PCA) on postoperative pain and safety after major abdominal surgery in elderly patients. Primary outcomes focused on postoperative pain, while secondary outcome measurements included the 
effect of both techniques on mental status as well as complications, including respiratory distress. Inclusion criteria were patient age older than 70 years, ASA class I or II, normal preoperative mental status, elective major abdominal surgery, absence of contraindications to epidural anesthesia, and the absence of extreme malnutrition or cerebral vascular insufficiency. After informed consent was obtained, included patients in this study were randomized by a table of random numbers to be placed in either the PCA group or PCEA group. A total of 108 patients were identified for potential enrollment into the trial; 38 were excluded, with the 70 remaining patients being enrolled and randomly assigned to one of the two treatment groups.

The 35 patients assigned to the PCA group received an initial loading dose of up to $5 \mathrm{mg}$ of IV morphine in the post-anesthesia care unit, followed by a programmed PCA pump delivering boluses of morphine $1.5 \mathrm{mg}$ with a lockout interval of 8 minutes. Thirtyfive patients in the PCEA group had an epidural catheter placed preoperatively. Epidural analgesia was started intraoperatively with a continuous infusion of $0.25 \%$ bupivacaine and sufentanil $1 \mathrm{mcg} / \mathrm{mL}$ mixture. Postoperatively PCEA was transitioned to $0.125 \%$ bupivacaine and sufentanil $0.5 \mathrm{mcg} / \mathrm{mL}$ mixture at a continuous infusion of $3-5 \mathrm{~mL} / \mathrm{hr}$ with 2-3 mL patient-controlled boluses at a lockout interval of 12 minutes (Mann et al., 2000).

Outcomes of this study by Mann et al. (2000) demonstrated a significance in regard to pain relief achieved with PCEA compared to that of PCA both at rest ( $p=$ $0.001)$ and after coughing $(p=0.002)$. Patient satisfaction was significantly greater for patients receiving PCEA than those receiving PCA $(p=0.012)$. There were no statistically significant differences in the incidence of pulmonary complications between 
the two groups in either frequency or type of complication (atelectasis, pneumonia, or hypoventilation).

When evaluating the study utilizing the CASP questionnaire (Appendix E, Table 5), it appears that Mann et al. (2000) addressed a clearly focused issue. All enrolled patients were randomized, and both treatment groups were similar at the start of the trial. Aside from experimental intervention, both groups were treated equally throughout the study period. Study personnel, healthcare workers, and patients were not blinded to the treatment modality during this trial. Results of this study may apply to elderly patients eligible to receive epidural anesthesia and analgesia. This study is limited in the size and scope of its study. The small number of patients included limits the ability to show accuracy in applying this data to the larger population. Additionally, while these results may apply to patients undergoing abdominal surgery, it may be difficult to apply to different patient populations who may not have met inclusionary criteria for this study. Mann et al. (2000) determined that PCEA provided better patient satisfaction and pain relief safely when compared to PCA in healthy elderly patients after major abdominal surgery.

A systematic review of randomized controlled trials by Duch and Moller (2015) (Appendix D, Table 6) assessed the effects of continuous epidural analgesia (CEA) compared with other interventions in patients with traumatic rib fractures. Included were six trials, measuring primary outcomes of mortality, pneumonia, and duration of mechanical ventilation. All included studies were single-center trials, with durations varying from 17 to 46 months. The included trials had a total enrollment of 223 patients. Three trials evaluated CEA with a local anesthetic and opioid, two evaluated CEA with 
opioid alone, and one with local anesthetic alone. These interventions were compared with IV analgesia in four of the studies, paravertebral block in one, and intercostal block in one trial.

Primary outcomes measured by Duch and Moller (2015) included: all-cause mortality, duration of mechanical ventilation, and rates of pneumonia. Data examining mortality was extracted from two trials $(n=76)$. After analysis, no significant difference was determined in mortality in patients treated with CEA versus other interventions $(p=$ 0.51). Of the four trials $(\mathrm{n}=133)$ that reported on duration of mechanical ventilation, Duch and Moller (2015) found no statistical difference in patients treated with CEA comparted to those treated with other interventions $(p=0.09)$. In all four of these trials, IV analgesia was utilized as the control group. Additionally, in three trials that reported on incidence of pneumonia $(n=108)$, no statistical significance was found between intervention and control groups $(p=0.13)$.

Investigation using the CASP questionnaire (Appendix E, Table 6) showed that the review focused on a clear question. Investigators looked at relevant and important studies, and Duch and Moller (2015) clearly assessed the quality of all included trials. Results can be applied to adult patients having sustained rib fractures, though the evidence quality is lacking in the support of use of CEA for these patients. All six trials examined by Duch and Moller (2015) were found to have a high risk of bias, due to lack of blinding of patients and personnel, as well as lack of blinding of outcome assessment. Four trials did not include results for the key outcome measure of mortality, giving them a high risk of reporting bias. This high risk of bias indicates poor quality and difficulty in interpretation of results. The data presented by Duch and Moller (2015) in this systematic 
review indicate the need for further research and higher quality evidence to determine the value of continuous epidural analgesia versus other interventions after traumatic rib fractures.

\section{Cross-Study Analysis}

The cross-study analysis table (Appendix F) shows the average age of patients included in each study, as well as major outcomes investigated associated with epidural analgesia including effects on pneumonia, respiratory failure, and mortality. It is notable that some studies did not investigate all of these variables. Mann et al. (2000), Moon et al. (1999), and Sakura et al. (1996) did not investigate the effects of epidural analgesia on pneumonia or mortality rates as variables, and rather focused on effects on pulmonary complications and respiratory failure.

All studies examined adult patients over the age of 18, with Mann et al. (2000) and Sakura et al. (1996) focusing primarily on older adult patients (65+ years old). Primary investigative treatment was thoracic epidural analgesia across all studies and was compared against systemic IV opioids (study 1, 2, and 3), IV PCA opioids (study 4 and 5), and lumbar epidural anesthesia (study 6). Data regarding the effect of epidural analgesia on incidence of pneumonia was mixed amongst the studies. McKendy et al. (2017) found rates to be higher, Bulger et al. (2004) found pneumonia rates to be lower, while a systematic review by Duch and Moller (2015) found no statistically significant data. Effects of epidural analgesia on respiratory failure and mechanical ventilation was largely statistically insignificant (study 1, 2, 3, 4). Moon et al. (1999) found maximal inspiratory force and tidal volume to be increased in the presence of epidural analgesia 
when compared to PCA. Sakura et al. (1996) found ventilatory response to hypercapnia and hypoxia to be preserved in the presence of epidural anesthesia, while minute ventilation did decrease significantly more with thoracic epidurals compared to lumbar. When examining the effect of epidural analgesia on mortality rates after rib fractures, Duch and Moller (2015) and Bulger et al. (2004) did not find statistically significant data when compared to systemic opioids. Conversely, McKendy et al. (2017) found patients treated with epidural analgesia to exhibits higher rates of mortality.

Next, the summary and conclusions will be presented. 


\section{Summary and Conclusions}

The purpose of this systematic review was to determine the effectiveness of epidural analgesia in decreasing the mortality of older adult patients with rib fractures. Background research was conducted on the physiological detriments of rib fractures, as well as various modalities for treating pain associated with such injuries. A literature review was completed focusing on physiological changes associated with aging, traumatic rib fractures and their effect on the older adult patient, and treatment of pain associated with rib fractures. A theoretical framework was outlined and utilized during this systematic review, and consisted of a 27-item checklist as well as four-phase flow diagram in accordance with PRISMA. Appropriate research utilized during this systematic review was identified and then screened for inclusion criteria and eligibility for this study.

Individual analysis was completed on the six included studies, utilizing data tables to adequately appraise five RCTs and one systematic review. Outcome specific data tables were also completed to determine the effect of epidural analgesia on rates of pneumonia, mortality, and respiratory complications. Critical Appraisal Skills Programme (CASP) checklists were utilized to critically evaluate the trials for validity and ability to apply the study results to the older adult patient population. Finally, a crossstudy analysis table was completed to compare the results from each study in the use of epidural analgesia for older adult patients with rib fractures.

Traumatic rib fractures are particularly troublesome for older adults. Physiologic changes associated with aging place this patient population at an increased risk for 
pulmonary complications and associated mortality after sustaining blunt thoracic trauma. As reported by Winters (2009), mortality associated with rib fractures increases approximately $5 \%$ with every year over age 65 . Treating pain associated with these injuries has been shown to be of utmost importance in preventing pulmonary complications such as pneumonia and respiratory failure; epidural analgesia was of particular interest in this systematic review.

Bulger, et al. (2000) reported in a retrospective cohort study that older adults sustaining rib fractures had an increased incidence of pulmonary complications, as well as increased mortality. These complications increased with an increase in number of ribs fractured, with those sustaining greater than six rib fractures having $33 \%$ mortality. Bulger, et al. (2000) went on to find that older adults experienced decreased mortality rates with the addition of epidural analgesia. This data was supported by a study by Gage, et al. (2013), which examined the efficacy of CEA in patients with greater than three rib fractures in decreasing mortality rates.

In practice management guidelines published by Galvagno et al. (2016), the use of epidural analgesia as opposed to opioids alone to treat pain after blunt thoracic trauma was conditionally recommended. This recommendation was based on low-quality evidence, and Galvagno et al. (2016) stated that stronger magnitude of effect may be observed if certain confounders such as age be taken into account. These results appear to correlate with the results found in this systematic review, which do not appear to reliably show a statistically significant effect of epidural analgesia decreasing mortality in the older adult population. 
Three of the six studies in this systematic review examined the effect of epidural analgesia on rates of pneumonia. While pneumonia rates were shown to be lower with the use of epidurals versus standard treatment with systemic opioids, none of the trials reported statistically significant data supporting the definitive use of epidurals in older adult patients. All six studies examined the effect of epidurals in preventing respiratory failure, with no statistically significant differences being found. Additionally, there was no statistically significant data to support decreased mortality after rib fractures with the use of CEA. Mann, et al. (2000) found that epidural analgesia provides better preservation of mental status and bowel function in older adult patients when compared to parenteral opioids. Sakura, et al. (1996) found that neither thoracic nor lumbar epidurals significantly impaired ventilatory response to hypercapnia and hypoxia in older adult patients, but that those receiving thoracic epidurals did experience slightly impaired resting ventilation.

There were several limitations to this systematic review. The lack of prospective data on older adult trauma patients impedes the ability to find statistically significant research necessary to draw definitive conclusions regarding the use of CEA after thoracic trauma. Much of the prospective data is aged, with more current studies relying on retrospective chart reviews and observational studies. Many retrospective studies, such as those presented previously in a review of the literature, find data to support the correlation between decreased mortality with the use of CEA and rib fractures in this population. However, prospective data is lacking, and the data presented is not statistically significant in supporting such an intervention. The lack of blinding was a limitation noted in all studies in this systematic review. Confounding variables such as 
patient-specific comorbidities precluding the use of epidural analgesia may apply to all studies examined. Furthermore, there is a lack of data specific to this patient population, making it difficult to draw meaningful conclusions for this at-risk group.

The findings of this systematic review determined that there is currently not enough statistically significant prospective data to state that epidural analgesia decreases mortality in older adult patients with rib fractures. Additionally, data does not definitively support the outcomes of decreased pulmonary complications such as pneumonia rates, or respiratory failure after traumatic rib fractures.

Next, the recommendations and implications for advanced nursing practice will be discussed. 


\section{Recommendations and Implications for Advanced Nursing Practice}

Rib fractures are an unfortunately common complication suffered by older adults after blunt force thoracic trauma. The pain associated with these injuries places these patients at an increased risk for pneumonia, respiratory failure, and death due to physiologic changes associated with aging. Winters (2009) reported that mortality associated with rib fractures increases approximately $5 \%$ with every year over age 65 . It has been documented that aggressive treatment of pain is imperative in prevention of such complications.

Certified Registered Nurse Anesthetists (CRNAs), as an important member of the anesthesia care team, have the ability to help guide the care and management of these patients. With numerous ways of treating an often fragile patient population, it is the responsibility of the advanced practice nurse to follow an individualized plan of care. The importance of patient individualization precludes the use of a single anesthetic plan for all patients, as recommended by AANA standards. This standard regarding anesthesia plan implementation and management, states that the prudent CRNA "implement and, if needed, modify the anesthesia plan of care by continuously assessing the patient's response to the anesthetic..." (AANA, 2013, p. 2). Additionally, patients are to be informed of their anesthetic options and be able to participate in the choice of a patientspecific plan for anesthesia care when at all possible.

The AANA (2014) offers guidelines for pain management, recognizing that CRNAs are "uniquely skilled to deliver pain treatment in a compassionate and holistic manner," (AANA, 2014, p. 1). CRNAs provide pain management services in a variety of 
different patient-care settings; they may act as members of pain management teams, receive referrals from other clinicians, or act as sole providers of pain management services. The AANA (2018) further cites that a preemptive and multimodal approach to managing acute pain has demonstrated a long-term positive effect for patients (AANA, 2018, p. 4). Regional anesthesia is a focal point of this multimodal approach, and CRNAs are highly skilled in providing such anesthetic care. The utilization of systematic reviews may aide in building a knowledge base of best practices for the anesthetist, by thoroughly evaluating evidence of multiple randomized trials.

The results of this systematic review were unable to determine statistically significant data supporting the definitive utilization of CEA for older adult patients with rib fractures. Further research is recommended to investigate the use of CEA for older adults with rib fractures. Though current practice guidelines recommend the use of epidurals as part of the treatment plan for thoracic trauma, there is little current prospective data involving this at risk population. Further research may allow for more concrete results in treating older adults. However, CEA does remain an effective treatment modality when considered as part of a multi-modal approach to pain management. 


\section{References}

American Association of Nurse Anesthetists (AANA). (2013). Standards for nurse anesthesia practice. Park Ridge, IL.

American Association of Nurse Anesthetists (AANA). (2014). Chronic pain management guidelines. Park Ridge, IL.

American Association of Nurse Anesthetists (AANA). (2018). Regional anesthesia and analgesia techniques - An element of multimodal pain management. Park Ridge, IL.

Barash, P.G., Cullen, B.F., Stoelting, R.K., Cahalan, M.K., \& Stock, M.C. (2009). Clinical anesthesia, $6^{\text {th }}$ ed. Philadelphia, PA: Lippincott Williams \& Wilkins.

Bulger, E.M., Arneson, M.A., Mock, C.N., \& Jurkovich, G.J. (2000). Rib fractures in the elderly. The Journal of Trauma: Injury, Infection, and Critical Care, 48(6), 1040-1047.

Bulger, E.M., Edwards, T., Klotz, P., \& Jurkovich, G.J. (2004). Epidural analgesia improves outcome after multiple rib fractures. Surgery, 136(2), 426-430.

Butterworth, J.F., Mackey, D.C., \& Wasnick, J.D. (2013). Morgan \& Mikhail's clinical anesthesiology, $5^{\text {th }}$ ed. New York, NY: McGraw-Hill.

Carr, D.B., \& Goudas, L.C. (1999). Acute pain. Lancet, 353, 2051-2058.

Critical Appraisal Skills Programme. (2017). CASP systematic review checklist [data file]. Retrieved from http://media.wix.com/ugd/dded87_7e983a320087439e9 4533f4697aa109c.pdf 
Duch, P., \& Moller, M.H. (2015). Epidural analgesia in patients with traumatic rib fractures: A systemic review of randomize controlled trials. Acta Anaesthesiologica Scandinavica, 59, 698-709.

Gage, A., Rivara, F., Wang, J., Jurkovich, G., \& Arbabi, S. (2013). The effect of epidural placement in patients after blunt thoracic trauma. Journal of Trauma and Acute Care Surgery, 76(1), 39-45.

Galvagno, S.M., Smith, C.E., Varon, A.J., Hasenboehler, E.A., Sultan, S., ...Haut, E.R. (2016). Pain management for blunt thoracic trauma: A joint practice management guideline from the Eastern Association for the Surgery of Trauma and Trauma Anesthesiology Society. Journal of Trauma and Acute Care Surgery, 81(5), 936950.

Herr, K.A., \& Garand, L. (2001). Assessment and measurement of pain in older adults. Clinical Geriatric Medicine, 17(3), 457-475.

Horlocker, T.T., Vandermeuelen, E., Kopp, S.L., Gogarten, W., Leffert, L.R., \& Benzon, H.T. (2018). Regional anesthesia in the patient receiving antithrombotic or thrombolytic therapy: American Society of Regional Anesthesia and Pain Medicine evidence-based guidelines $4^{\text {th }}$ ed. Regional Anesthesia and Acute Pain, 43, 263-309.

Karmakar, M.K., Critchley, L.A.H., Ho, A.M., Gin, T., Lee, T.W., \& Yim, A.P. (2003). Continuous thoracic paravertebral infusion of bupivacaine for pain management in patients with multiple fractured ribs. Chest Journal, 123(2), 424-430. 
Leininger, S. (2017). Rib fracture protocol advancing the care of the elderly patient. Critical Care Nursing Quarterly, 40(1), 24-28.

Liberati, A., Altman, D.G., Tetzlaff, J., Mulrow, C., Gotzsche, P.C., ...Moher, D. (2009). The PRISMA statement for reporting systematic reviews and meta-analyses of studies that evaluate health care interventions: Explanation and elaboration. PLoS Medicine, 6(7), 1-28.

Mann, C., Pouzeratte, Y., Boccara, G., Peccoux, C., Vergne, C., Brunat, G.,...Colson, P. (2000). Comparison of intravenous or epidural patient-controlled analgesia in the elderly after major abdominal surgery. Anesthesiology, 92(2), 433-44.

McKendy, K.M., Lee, L.F., Boulva, K., Deckelbaum, D.L., Mulder, D.S., Razek, T.S., \& Grushka, J.R. (2017). Epidural analgesia for traumatic rib fractures is associated with worse outcomes: a matched analysis. Journal of Surgical Research, 214, 117-123.

Moher, D.M., Liberati, A., Tetzlaff, J., Altman, D.G., \& the PRISMA Group (2009). Preferred reporting items for systematic reviews and meta-analyses: The PRISMA statement. Annals of Internal Medicine, 151(4), 264-269.

Moon, M.R., Luchetter, F.A., Gibson, S.W., Crews, J., Sudarshan, G., Hurst, J.M., ...Fischer, J.E. (1999). Prospective, randomized comparison of epidural versus parenteral opioid analgesia in thoracic trauma. Annals of Surgery, 229(5), 684692.

Nagelhout, J.J., \& Plaus, K.L. (2014). Nurse anesthesia, $5^{\text {th }}$ ed. St. Louis, MO: Elsevier 
New York School of Regional Anesthesia [NYSORA] (2018). Continuous thoracic paravertebral block. Retrieved from https://www.nysora.com/continuous-thoracicparavertebral-block.

Polit, D., \& Beck, C. (2017). Nursing research: Generating and assessing evidence for nursing practice. (10 ${ }^{\text {th }}$ ed.). Philadelphia, PA: Wolters Kluwer: Lippincott Williams \& Wilkins.

Royal College of Physicians, British Geriatrics Society, \& British Pain Society (2007). The assessment of pain in older people: National guidelines. Retrieved from https://www.britishpainsociety.org/static/uploads/resources/files/book_pain_older _people.pdf

Saher, S.M., Webb, M.L., Renner, C.H., Sokol, R.K., \& Swegle, J.R. (2013). Implementation of a rib fracture triage protocol in elderly trauma patients. Journal of Trauma Nursing, 20(4), 172-175.

Sakura, S., Saito, Y., \& Kosaka, Y. (1996). The effects of epidural anesthesia on ventilatory response to hypercapnia and hypoxia in elderly patients. Anesthesia Analgesia, 82, 306-311.

Stawicki, S.P., Grossman, M.D., Hoey, B.A., Miller, D.L., \& Reed III, J.F. (2004). Rib fractures in the elderly: A marker for injury severity. Journal of the American Geriatrics Society, 52(5), 805-808.

Winters, B.A. (2009). Older adults with traumatic rib fractures: An evidence-based approach to their care. Journal of Trauma Nursing, 16(2), 93-97. 


\section{Appendix A}

PRISMA Checklist (Moher et al., 2009)

\begin{tabular}{|c|c|c|c|}
\hline Section/topic & $\#$ & Checklist item & $\begin{array}{l}\text { Reported } \\
\text { on page \# }\end{array}$ \\
\hline \multicolumn{4}{|l|}{ TITLE } \\
\hline Title & 1 & Identify the report as a systematic review, meta-analysis, or both. & \\
\hline \multicolumn{4}{|l|}{ ABSTRACT } \\
\hline Structured summary & 2 & $\begin{array}{l}\text { Provide a structured summary including, as applicable: background; objectives; data sources; study eligibility criteria, } \\
\text { participants, and interventions; study appraisal and synthesis methods; results; limitations; conclusions and } \\
\text { implications of key findings; systematic review registration number. }\end{array}$ & \\
\hline \multicolumn{4}{|l|}{ INTRODUCTION } \\
\hline Rationale & 3 & Describe the rationale for the review in the context of what is already known. & \\
\hline Objectives & 4 & $\begin{array}{l}\text { Provide an explicit statement of questions being addressed with reference to participants, interventions, comparisons, } \\
\text { outcomes, and study design (PICOS). }\end{array}$ & \\
\hline \multicolumn{4}{|l|}{ METHODS } \\
\hline Protocol and registration & 5 & $\begin{array}{l}\text { Indicate if a review protocol exists, if and where it can be accessed (e.g., Web address), and, if available, provide } \\
\text { registration information including registration number. }\end{array}$ & \\
\hline Eligibility criteria & 6 & $\begin{array}{l}\text { Specify study characteristics (e.g., PICOS, length of follow-up) and report characteristics (e.g., years considered, } \\
\text { language, publication status) used as criteria for eligibility, giving rationale. }\end{array}$ & \\
\hline Information sources & 7 & $\begin{array}{l}\text { Describe all information sources (e.g., databases with dates of coverage, contact with study authors to identify } \\
\text { additional studies) in the search and date last searched. }\end{array}$ & \\
\hline Search & 8 & $\begin{array}{l}\text { Present full electronic search strategy for at least one database, including any limits used, such that it could be } \\
\text { repeated. }\end{array}$ & \\
\hline Study selection & 9 & $\begin{array}{l}\text { State the process for selecting studies (i.e., screening, eligibility, included in systematic review, and, if applicable, } \\
\text { included in the meta-analysis). }\end{array}$ & \\
\hline Data collection process & 10 & $\begin{array}{l}\text { Describe method of data extraction from reports (e.g., piloted forms, independently, in duplicate) and any processes } \\
\text { for obtaining and confirming data from investigators. }\end{array}$ & \\
\hline Data items & 11 & $\begin{array}{l}\text { List and define all variables for which data were sought (e.g., PICOS, funding sources) and any assumptions and } \\
\text { simplifications made. }\end{array}$ & \\
\hline $\begin{array}{l}\text { Risk of bias in individual } \\
\text { studies }\end{array}$ & 12 & $\begin{array}{l}\text { Describe methods used for assessing risk of bias of individual studies (including specification of whether this was } \\
\text { done at the study or outcome level), and how this information is to be used in any data synthesis. }\end{array}$ & \\
\hline Summary measures & 13 & State the principal summary measures (e.g., risk ratio, difference in means). & \\
\hline Synthesis of results & 14 & $\begin{array}{l}\text { Describe the methods of handling data and combining results of studies, if done, including measures of consistency } \\
\left.\text { (e.g., } 1^{2}\right) \text { for each meta-analysis. }\end{array}$ & \\
\hline Section/topic & $\#$ & Checklist item & $\begin{array}{l}\text { Reported } \\
\text { on page \# }\end{array}$ \\
\hline Risk of bias across studies & 15 & $\begin{array}{l}\text { Specify any assessment of risk of bias that may affect the cumulative evidence (e.g., publication bias, selective } \\
\text { reporting within studies). }\end{array}$ & \\
\hline Additional analyses & 16 & $\begin{array}{l}\text { Describe methods of additional analyses (e.g., sensitivity or subgroup analyses, meta-regression), if done, indicating } \\
\text { which were pre-specified. }\end{array}$ & \\
\hline \multicolumn{4}{|l|}{ RESULTS } \\
\hline Study selection & 17 & $\begin{array}{l}\text { Give numbers of studies screened, assessed for eligibility, and included in the review, with reasons for exclusions at } \\
\text { each stage, ideally with a flow diagram. }\end{array}$ & \\
\hline Study characteristics & 18 & $\begin{array}{l}\text { For each study, present characteristics for which data were extracted (e.g., study size, PICOS, follow-up period) and } \\
\text { provide the citations. }\end{array}$ & \\
\hline Risk of bias within studies & 19 & Present data on risk of bias of each study and, if available, any outcome level assessment (see item 12). & \\
\hline Results of individual studies & 20 & $\begin{array}{l}\text { For all outcomes considered (benefits or harms), present, for each study: (a) simple summary data for each } \\
\text { intervention group (b) effect estimates and confidence intervals, ideally with a forest plot. }\end{array}$ & \\
\hline Synthesis of results & 21 & Present results of each meta-analysis done, including confidence intervals and measures of consistency. & \\
\hline Risk of bias across studies & 22 & Present results of any assessment of risk of bias across studies (see Item 15). & \\
\hline Additional analysis & 23 & Give results of additional analyses, if done (e.g., sensitivity or subgroup analyses, meta-regression [see Item 16]). & \\
\hline \multicolumn{4}{|l|}{ DISCUSSION } \\
\hline Summary of evidence & 24 & $\begin{array}{l}\text { Summarize the main findings including the strength of evidence for each main outcome; consider their relevance to } \\
\text { key groups (e.g., healthcare providers, users, and policy makers). }\end{array}$ & \\
\hline Limitations & 25 & $\begin{array}{l}\text { Discuss limitations at study and outcome level (e.g., risk of bias), and at review-level (e.g., incomplete retrieval of } \\
\text { identified research, reporting bias). }\end{array}$ & \\
\hline Conclusions & 26 & Provide a general interpretation of the results in the context of other evidence, and implications for future research. & \\
\hline \multicolumn{4}{|l|}{ FUNDING } \\
\hline Funding & 27 & $\begin{array}{l}\text { Describe sources of funding for the systematic review and other support (e.g., supply of data); role of funders for the } \\
\text { systematic review. }\end{array}$ & \\
\hline
\end{tabular}




\section{Appendix B}

Critical Appraisal Skills Programme (CASP) Randomized Control Trials Checklist (2017)

\begin{tabular}{|c|c|c|c|}
\hline A. Are the results of the Trial Valid? & Yes & Can't Tell & No \\
\hline \multicolumn{4}{|l|}{ 1. Did the trial address a clearly focused issue? } \\
\hline \multicolumn{4}{|l|}{$\begin{array}{l}\text { 2. Was the assignment of patients to treatments } \\
\text { randomized? }\end{array}$} \\
\hline \multicolumn{4}{|l|}{$\begin{array}{l}\text { 3. Were all of the patients who entered the trial } \\
\text { properly accounted for at its conclusion? }\end{array}$} \\
\hline \multicolumn{4}{|l|}{$\begin{array}{l}\text { 4. Were patients, health workers and study } \\
\text { personnel "blind" to treatment? }\end{array}$} \\
\hline \multicolumn{4}{|l|}{$\begin{array}{l}\text { 5. Were the groups similar at the start of the } \\
\text { trial? }\end{array}$} \\
\hline \multicolumn{4}{|l|}{$\begin{array}{l}\text { 6. Aside from the experimental intervention, } \\
\text { were the groups treated equally? }\end{array}$} \\
\hline \multicolumn{4}{|l|}{ B. What are the results? } \\
\hline \multicolumn{4}{|l|}{ 7. How large was the treatment effect? } \\
\hline \multicolumn{4}{|l|}{$\begin{array}{l}\text { 8. How precise was the estimate of the treatment } \\
\text { effect? }\end{array}$} \\
\hline C. Will the results help locally? & Yes & Can't Tell & No \\
\hline \multicolumn{4}{|l|}{$\begin{array}{l}\text { 9. Can the results be applied to the local } \\
\text { population, or in your context? }\end{array}$} \\
\hline \multicolumn{4}{|l|}{$\begin{array}{l}\text { 10. Were all clinically important outcomes } \\
\text { considered? }\end{array}$} \\
\hline 11. Are the benefits worth the harms and costs? & & & \\
\hline
\end{tabular}




\section{Appendix C}

PRISMA 2009 Flow Diagram

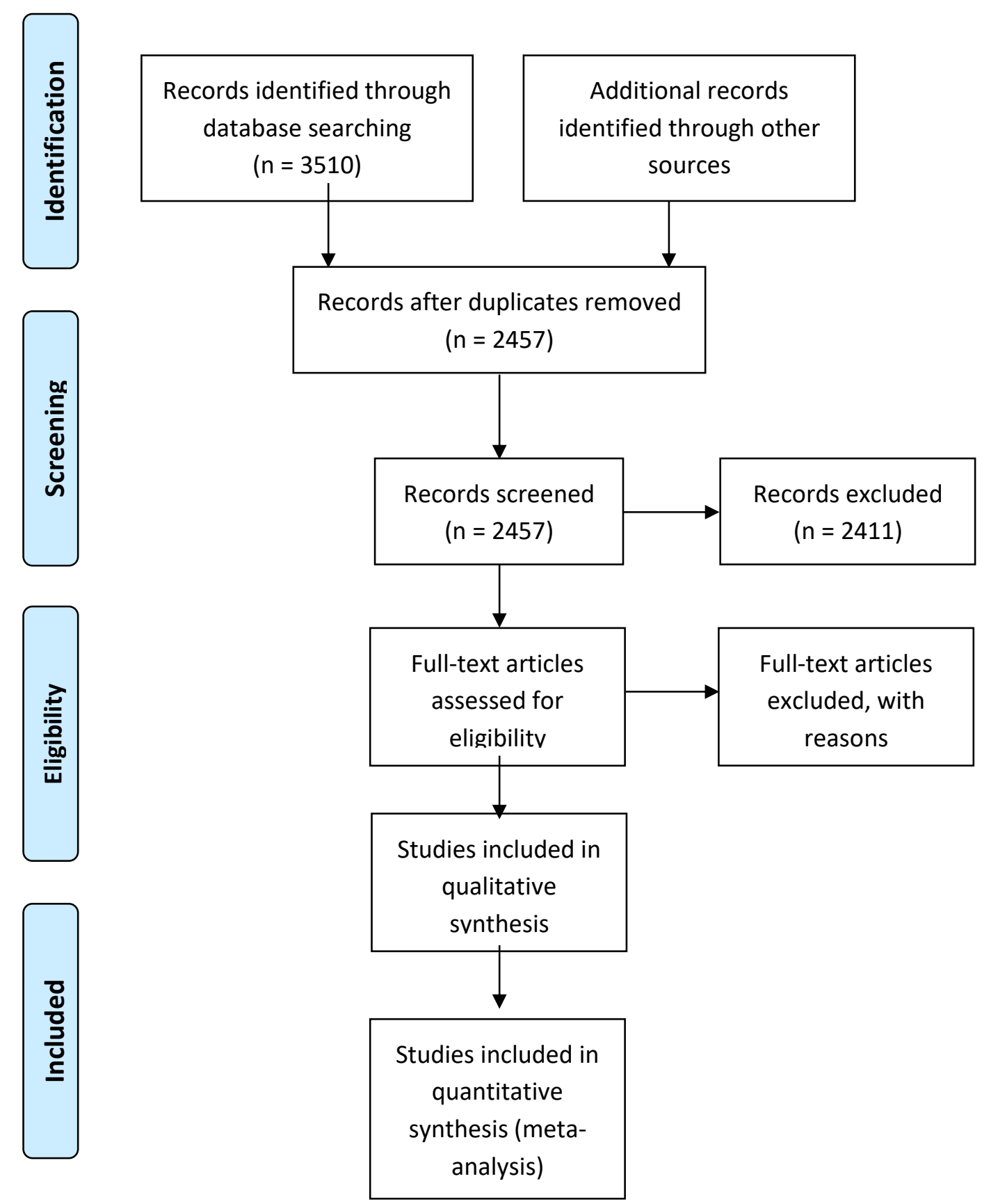




\section{Appendix D: Data Analysis Tables}

Table D-1: McKendy, K.M., Lee, L.F., Boulva, K., Deckelbaum, D.L., Mulder, D.S., Razek, T.S., \& Grushka, J.R. (2017). Epidural analgesia for traumatic rib fractures is associated with worse outcomes: a matched analysis. Journal of Surgical Research, 214, 117-123.

\begin{tabular}{|c|c|c|c|c|c|c|c|c|}
\hline Purpose & $\begin{array}{c}\text { Study } \\
\text { Design }\end{array}$ & & Sample & Intervention & Comparison & Outcomes & Findings & Limitations \\
\hline $\begin{array}{l}\text { To } \\
\text { determine } \\
\text { the effect of } \\
\text { epidural } \\
\text { analgesia on } \\
\text { the incidence } \\
\text { of } 30 \text { day in- } \\
\text { hospital } \\
\text { mortality } \\
\text { and } \\
\text { respiratory } \\
\text { complication } \\
\text { s in adult } \\
\text { patients with } \\
\text { rib fractures. }\end{array}$ & $\begin{array}{l}\text { Prospective } \\
\text {, matched } \\
\text { analysis } \\
\text { study }\end{array}$ & - & $\begin{array}{l}\text { Total of } \\
2270 \text { adult } \\
\text { patients } \\
\text { presented to } \\
\text { a Level 1 } \\
\text { Trauma } \\
\text { Center } \\
\text { between } \\
2004-2013 \\
\text { who had } \\
\text { sustained at } \\
\text { least one rib } \\
\text { fracture } \\
\text { secondary } \\
\text { to blunt } \\
\text { trauma were } \\
\text { queried } \\
\text { from a } \\
\text { prospectivel } \\
\text { y entered } \\
\text { database. } \\
1360 \\
\text { patients met } \\
\text { inclusion }\end{array}$ & $\begin{array}{l}\text { Epidural } \\
\text { analgesia. The } \\
\text { decision to utilize } \\
\text { this modality was } \\
\text { made by the } \\
\text { treating physician. } \\
\text { - If utilized, the } \\
\text { epidural was } \\
\text { placed by an } \\
\text { anesthesiologi } \\
\text { st within } 24 \\
\text { hours of the } \\
\text { patient } \\
\text { presenting to } \\
\text { the hospital }\end{array}$ & $\begin{array}{l}\text { Standard } \\
\text { management } \\
\text { by treating } \\
\text { physician, } \\
\text { with a } \\
\text { combination } \\
\text { of opioids } \\
\text { and } \\
\text { nonsteroidal } \\
\text { anti- } \\
\text { inflammatory } \\
\text { agents } \\
\text { titrated to the } \\
\text { patient's pain } \\
\text { levels. } \\
\text { - These } \\
\text { patients } \\
\text { did NOT } \\
\text { receive } \\
\text { any } \\
\text { intercosta } \\
1 \text { nerve } \\
\text { blocks or } \\
\text { other }\end{array}$ & $\begin{array}{l}\text { - 30-day in- } \\
\text { hospital } \\
\text { mortality. } \\
\text { - } \\
\text { Respiratory } \\
\text { complication } \\
\text { s: } \\
\text { pneumonia, } \\
\text { pulmonary } \\
\text { embolism, } \\
\text { respiratory } \\
\text { failure. }\end{array}$ & $\begin{array}{l}\text { Patients } \\
\text { receiving } \\
\text { epidurals } \\
\text { experienced } \\
\text { more } \\
\text { respiratory } \\
\text { complication } \\
\mathrm{s}-19 \% \\
\text { versus } 10 \% \\
\text { (p=0.009) } \\
\text { 4\% overall } \\
\text { mortality; no } \\
\text { statistical } \\
\text { difference } \\
\text { between } \\
\text { groups in } \\
\text { either } \\
\text { unmatched } \\
\text { or matched } \\
\text { analysis. }\end{array}$ & 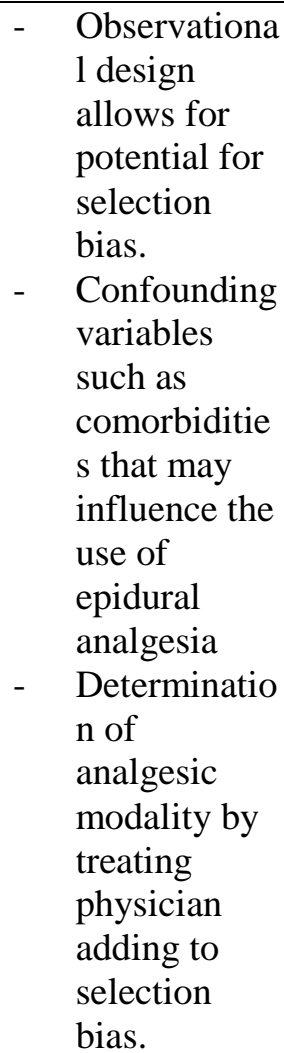 \\
\hline
\end{tabular}




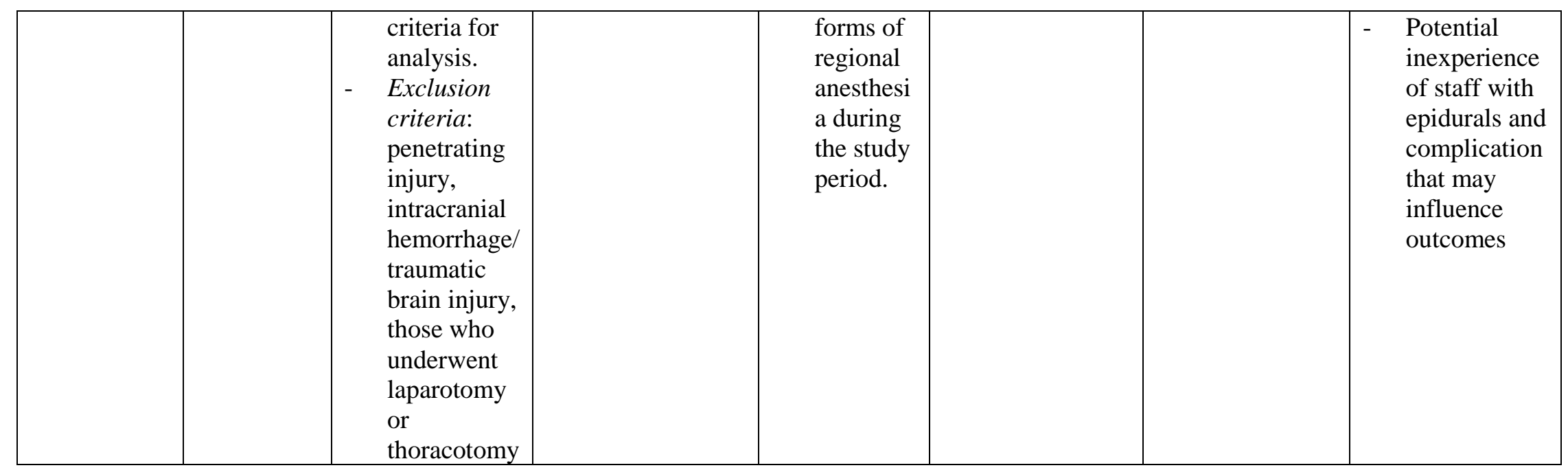


Table D-2: Bulger, E.M., Edwards, T., Klotz, P., \& Jurkovich, G.J. (2004). Epidural analgesia improves outcome after multiple rib fractures.

Surgery, 136(2), 426-430.

\begin{tabular}{|c|c|c|c|c|c|c|c|}
\hline Purpose & Study Design & Sample & Intervention & Comparison & Outcomes & Findings & Limitations \\
\hline $\begin{array}{l}\text { To determine } \\
\text { if epidural } \\
\text { analgesia } \\
\text { would reduce } \\
\text { the risk of } \\
\text { pneumonia } \\
\text { and duration } \\
\text { of mechanical } \\
\text { ventilation } \\
\text { when } \\
\text { compared to } \\
\text { IV opioids } \\
\text { after multiple } \\
\text { rib fractures. }\end{array}$ & $\begin{array}{l}\text { Prospective, } \\
\text { randomized } \\
\text { trial }\end{array}$ & $\begin{array}{l}46 \text { patients over } \\
18 \text { years old with } \\
3 \text { or more rib } \\
\text { fractures; } \\
\text { admitted to Level } \\
1 \text { trauma center } \\
\text { between March 1, } \\
2000 \text { and } \\
\text { December 15, } \\
2003 \text {. } \\
22 \text { patients were } \\
\text { randomized to } \\
\text { epidural group } \\
\text { and } 24 \text { to } \\
\text { systemic opioid } \\
\text { group. } \\
\text { Patients excluded } \\
\text { in the presence of } \\
\text { acute spine } \\
\text { fracture, pre- } \\
\text { existing spinal } \\
\text { deformity, severe } \\
\text { brain or spinal } \\
\text { cord injury, } \\
\text { severe alteration } \\
\text { in mental status, }\end{array}$ & $\begin{array}{l}\text { Epidural } \\
\text { analgesia with } \\
\text { bupivacaine, } \\
\text { morphine, and } \\
\text { fentanyl. }\end{array}$ & $\begin{array}{l}\text { IV opioid } \\
\text { analgesia } \\
\text { administered by } \\
\text { patient- } \\
\text { controlled } \\
\text { analgesia (PCA) } \\
\text { - morphine, } \\
\text { hydromorphone, } \\
\text { and fentanyl. }\end{array}$ & 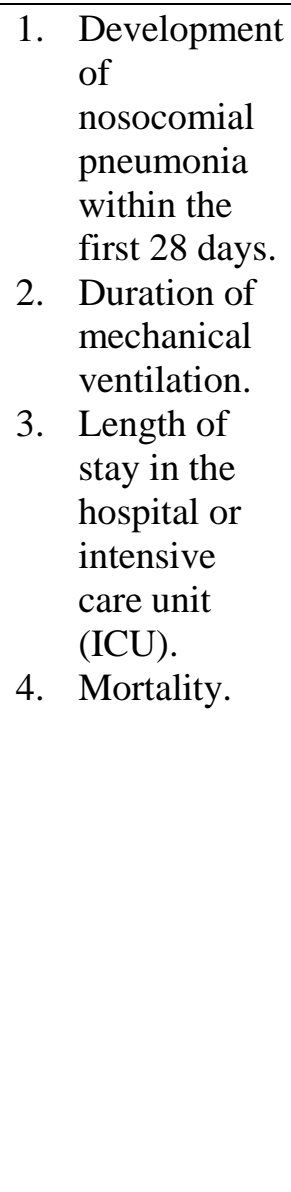 & $\begin{array}{l}\text { Those in the } \\
\text { epidural group } \\
\text { tended to have } \\
\text { more flail } \\
\text { segments, } \\
\text { pulmonary } \\
\text { contusions, } \\
\text { and more } \\
\text { likely to have } \\
\text { chest tube. } \\
\text { Pneumonia } \\
\text { rates: } 18 \% \text { in } \\
\text { epidural group } \\
\text { and } 38 \% \text { in } \\
\text { systemic } \\
\text { opioid group. } \\
\text { Mechanical } \\
\text { ventilation: } \\
\text { mean of } 7.6 \\
\text { days in } \\
\text { epidural group } \\
\text { and } 9.1 \text { days } \\
\text { in systemic } \\
\text { opioid group. }\end{array}$ & $\begin{array}{l}\text { Sample size - } \\
\text { only } 37 \% \text { of } \\
\text { patients who } \\
\text { met eligibility } \\
\text { criteria for the } \\
\text { study are } \\
\text { represented. } \\
\text { Due to } \\
\text { inability to } \\
\text { obtain consent, } \\
\text { patient/family } \\
\text { refusal. } 10 \\
\text { patients } \\
\text { excluded due } \\
\text { to physician } \\
\text { refusal, } \\
\text { introducing } \\
\text { selection bias. } \\
\text { Inability to } \\
\text { blind care } \\
\text { providers or } \\
\text { patients. } \\
\text { Exclusionary } \\
\text { criteria for }\end{array}$ \\
\hline
\end{tabular}




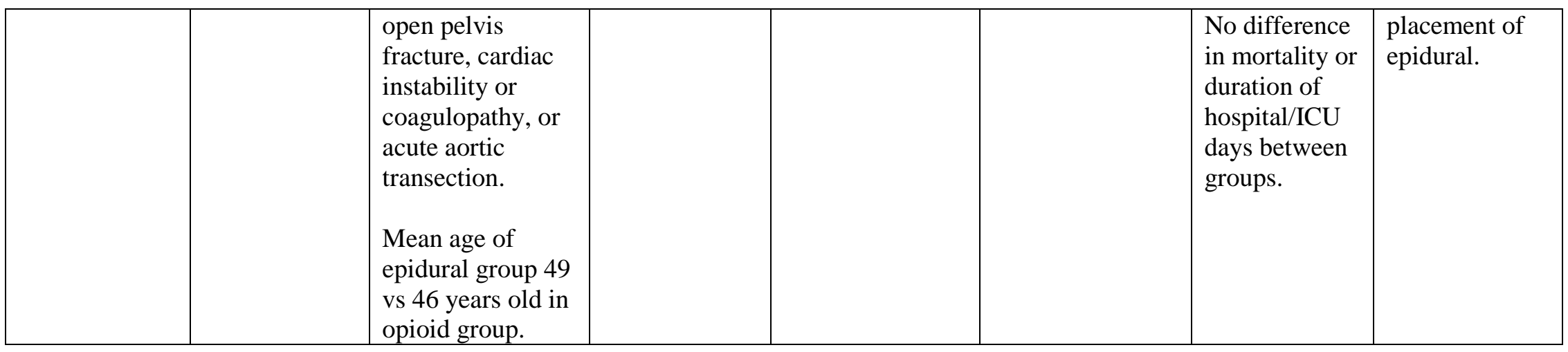


Table D-3: Moon, M.R., Luchetter, F.A., Gibson, S.W., Crews, J., Sudarshan, G., Hurst, J.M., ...Fischer, J.E. (1999). Prospective, randomized comparison of epidural versus parenteral opioid analgesia in thoracic trauma. Annals of Surgery, 229(5), 684-692.

\begin{tabular}{|c|c|c|c|c|c|c|c|}
\hline Purpose & $\begin{array}{l}\text { Study } \\
\text { Design }\end{array}$ & Sample & Intervention & Comparison & Outcomes & Findings & Limitations \\
\hline $\begin{array}{l}\text { To evaluate } \\
\text { systemic } \\
\text { versus epidural } \\
\text { opioid } \\
\text { administration } \\
\text { for analgesia } \\
\text { in patients who } \\
\text { have sustained } \\
\text { thoracic } \\
\text { trauma. }\end{array}$ & $\begin{array}{l}\text { Prospective, } \\
\text { randomized } \\
\text { study carried } \\
\text { out over } 18 \\
\text { months. }\end{array}$ & $\begin{array}{l}\text { Patients aged } \\
\text { 18-60 with } \\
\text { significant } \\
\text { trauma defined } \\
\text { as one or more } \\
\text { of the } \\
\text { following: } \\
\text { - } \quad \text { Three or } \\
\text { more } \\
\text { consecutive } \\
\text { rib fractures } \\
\text { - Flail chest } \\
\quad \text { segment } \\
\text { - Pulmonary } \\
\quad \text { contusion } \\
\text { - Sternal } \\
\text { fracture } \\
\text { Computer- } \\
\text { generated } \\
\text { numbers } \\
\text { randomized } \\
\text { patients into } \\
\text { two groups. } \\
\text { N=24 }\end{array}$ & $\begin{array}{l}\text { Thoracic } \\
\text { epidural } \\
\text { catheter } \\
\text { placement } \\
\text { between T5 } \\
\text { and T7. } \\
\text { Continuous } \\
\text { infusion of } \\
\text { bupivacaine } \\
0.25 \% \text { and } \\
\text { morphine } \\
0.005 \% \text { at a } \\
\text { rate of 4-6 } \\
\text { mL/hr. } \\
\text { Pain relief for } \\
\text { both groups } \\
\text { was assessed } \\
\text { using a } \\
\text { standard } \\
\text { verbal rating } \\
\text { scale 0-10. } \\
\text { During the } \\
\text { first hour, } \\
\text { verbal rating } \\
\text { scores were } \\
\text { assessed by }\end{array}$ & $\begin{array}{l}\text { Patient- } \\
\text { controlled } \\
\text { analgesia } \\
\text { (PCA) with a } \\
\text { loading dose } \\
\text { of intravenous } \\
\text { morphine } 0.1 \\
\text { mg/kg before } \\
\text { establishment } \\
\text { of PCA. } \\
\text { Infusion was } \\
\text { titrated by } \\
\text { member of the } \\
\text { acute pain } \\
\text { service to } \\
\text { maximize } \\
\text { relief. } \\
\text { Bolus doses of } \\
2 \text { mg with } \\
\text { lock-out } \\
\text { duration of } 10 \\
\text { minutes; no } \\
\text { background } \\
\text { infusion. }\end{array}$ & $\begin{array}{l}\text { 1. Cytokine } \\
\text { measurement } \\
\text { 2. Catecholamine } \\
\text { measurement } \\
\text { 3. Pulmonary } \\
\text { function } \\
\text { 4. Analgesia }\end{array}$ & 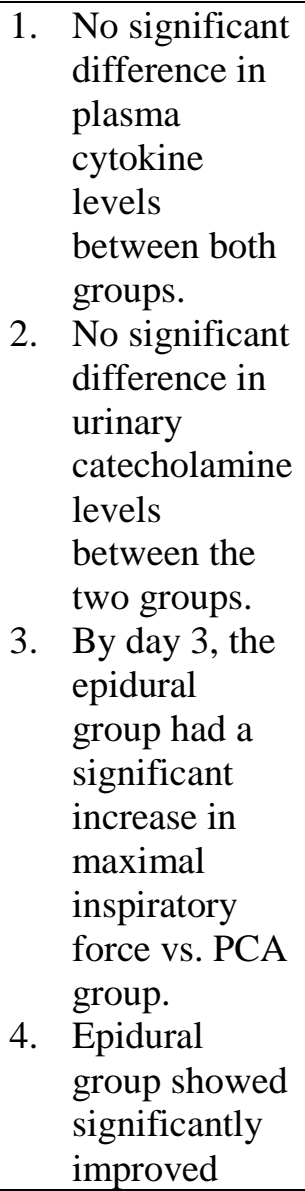 & $\begin{array}{l}\text { Small sample } \\
\text { size limits } \\
\text { accurate } \\
\text { interpretation } \\
\text { of results. A } \\
\text { larger sample } \\
\text { may show } \\
\text { more } \\
\text { significant } \\
\text { differences. }\end{array}$ \\
\hline
\end{tabular}




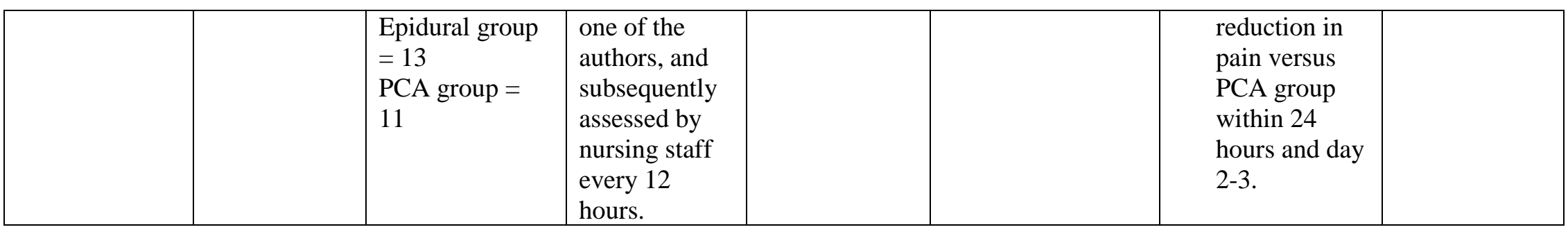


Table D-4: Sakura, S., Saito, Y., \& Kosaka, Y. (1996). The effects of epidural anesthesia on ventilatory response to hypercapnia and hypoxia in elderly patients. Anesthesia Analgesia, 82, 306-311.

\begin{tabular}{|c|c|c|c|c|c|c|c|}
\hline Purpose & Study Design & Sample & Intervention & Comparison & Outcomes & Findings & Limitations \\
\hline $\begin{array}{l}\text { To determine } \\
\text { if thoracic } \\
\text { epidural } \\
\text { anesthesia } \\
\text { will result in } \\
\text { impaired } \\
\text { response to } \\
\text { hypercapnia } \\
\text { and hypoxia } \\
\text { as compared } \\
\text { with lumbar } \\
\text { epidural } \\
\text { anesthesia in } \\
\text { elderly } \\
\text { patients. }\end{array}$ & $\begin{array}{l}\text { Two groups } \\
\text { were studied } \\
\text { twice before } \\
\text { and } 20 \\
\text { minutes after } \\
\text { administration } \\
\text { of lumbar or } \\
\text { thoracic } \\
\text { epidural } \\
\text { anesthesia. } \\
\text { Baseline } \\
\text { measurements } \\
\text { were obtained } \\
\text { on the day } \\
\text { before } \\
\text { surgery, by } \\
\text { hypercapnic } \\
\text { ventilatory } \\
\text { stimulation } \\
\text { test and } \\
\text { progressive } \\
\text { isocapnic } \\
\text { hypoxic } \\
\text { ventilatory } \\
\text { stimulation } \\
\text { test. }\end{array}$ & $\begin{array}{l}\text { Two groups of } 8 \\
\text { patients }(\mathrm{n}=16) \\
\text { aged } 65 \text { years or } \\
\text { older. } \\
\text { All patients were } \\
\text { ASA class I or } \\
\text { II, had no } \\
\text { history of } \\
\text { cardiopulmonary } \\
\text { disease, and had } \\
\text { not received } \\
\text { premedication. }\end{array}$ & $\begin{array}{l}\text { Group 1: } \\
\text { patients } \\
\text { undergoing } \\
\text { lower } \\
\text { abdominal } \\
\text { surgery } \\
\text { received } \\
\text { lumbar } \\
\text { epidural } \\
\text { anesthesia. } \\
\text { Test dose of } 1 \\
\text { mL of } 2 \% \\
\text { lidocaine } \\
\text { injected into } \\
\text { the epidural } \\
\text { space, } \\
\text { followed by } \\
10 \text { mL of } 2 \% \\
\text { lidocaine. }\end{array}$ & $\begin{array}{l}\text { Group 2: } \\
\text { patients } \\
\text { undergoing } \\
\text { upper } \\
\text { abdominal } \\
\text { surgery } \\
\text { received } \\
\text { thoracic } \\
\text { epidural } \\
\text { anesthesia. } \\
\text { Test dose and } \\
\text { epidural } \\
\text { injection were } \\
\text { identical to } \\
\text { the group } \\
\text { receiving } \\
\text { lumbar } \\
\text { epidural } \\
\text { anesthesia. }\end{array}$ & 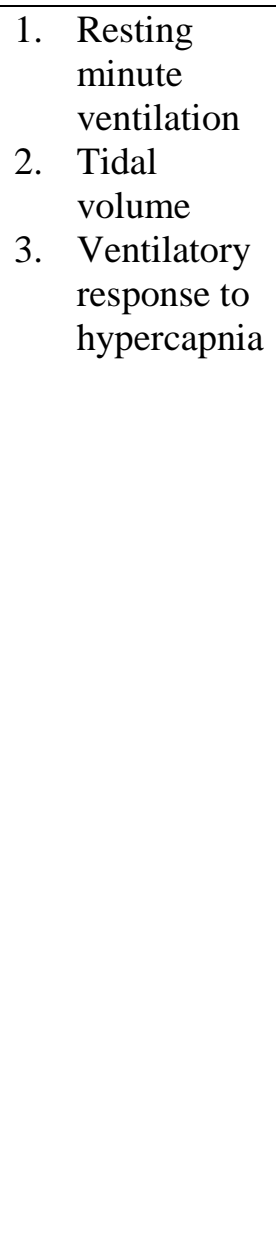 & 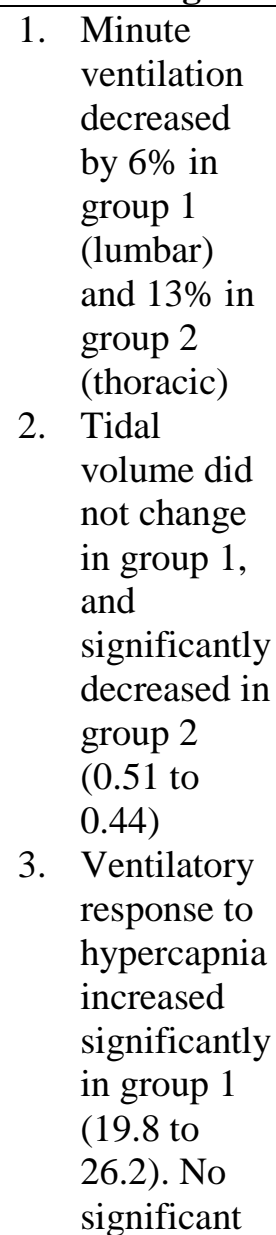 & $\begin{array}{l}\text { - Results } \\
\text { between the } \\
\text { groups may } \\
\text { not be directly } \\
\text { comparable } \\
\text { since there } \\
\text { was no } \\
\text { randomization } \\
\text { The same dose } \\
\text { of anesthetic } \\
\text { was given in } \\
\text { both groups, } \\
\text { which may } \\
\text { have caused } \\
\text { differences in } \\
\text { spread of } \\
\text { anesthesia. } \\
\text { Less volume } \\
\text { of local } \\
\text { anesthetic is } \\
\text { usually given } \\
\text { at higher } \\
\text { epidural } \\
\text { levels, so } \\
\text { results from } \\
\text { this study may } \\
\text { be } \\
\text { exaggerated. }\end{array}$ \\
\hline
\end{tabular}




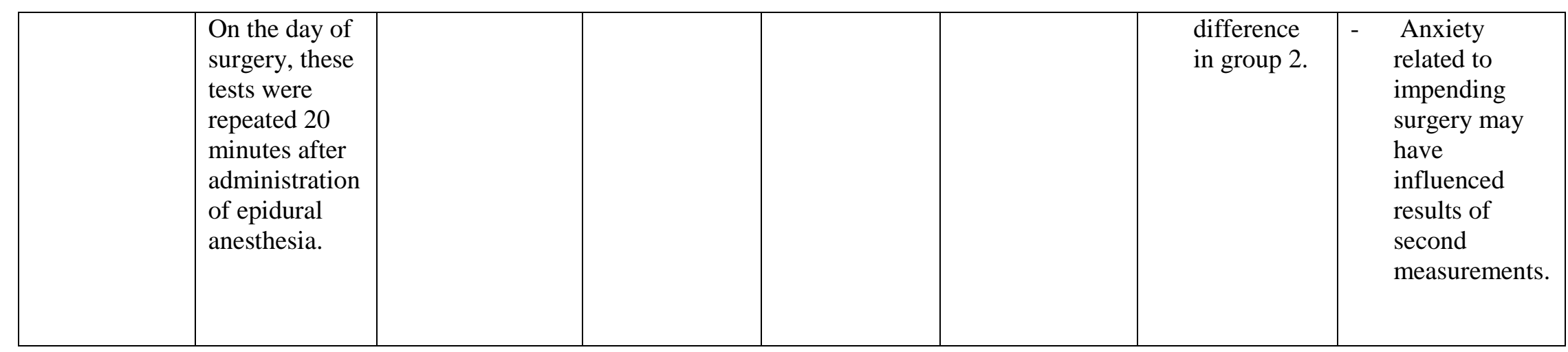


Table D-5: Mann, C., Pouzeratte, Y., Boccara, G., Peccoux, C., Vergne, C., Brunat, G.,...Colson, P. (2000). Comparison of intravenous or epidural patient-controlled analgesia in the elderly after major abdominal surgery. Anesthesiology, 92(2), 433-44.

\begin{tabular}{|c|c|c|c|c|c|c|c|}
\hline Purpose & $\begin{array}{l}\text { Study } \\
\text { Design }\end{array}$ & Sample & Intervention & Comparison & Outcomes & Findings & Limitations \\
\hline $\begin{array}{l}\text { To compare } \\
\text { the safety and } \\
\text { effectiveness } \\
\text { of patient } \\
\text { controlled } \\
\text { epidural } \\
\text { analgesia } \\
\text { (PCEA) } \\
\text { versus PCA } \\
\text { with } \\
\text { intravenous } \\
\text { morphine } \\
\text { following } \\
\text { major } \\
\text { abdominal } \\
\text { surgery }\end{array}$ & $\begin{array}{l}\text { Prospective } \\
\text { randomized } \\
\text { study carried } \\
\text { out for } 18 \\
\text { months. }\end{array}$ & $\begin{array}{l}\text { Patients older } \\
\text { than } 70 \text { years, } \\
\text { ASA status I or } \\
\text { II, normal } \\
\text { preoperative } \\
\text { mental status. } \\
\text { Electively } \\
\text { undergoing } \\
\text { major abdominal } \\
\text { surgery for } \\
\text { cancer via } \\
\text { midline or } \\
\text { subcostal } \\
\text { incision. } \\
\text { Absence of } \\
\text { contraindications } \\
\text { to epidural } \\
\text { placement: } \\
\text { coagulopathy, } \\
\text { localized } \\
\text { infection. } \\
\text { Patients } \\
\text { randomly } \\
\text { assigned to }\end{array}$ & $\begin{array}{l}\text { PCEA with } \\
0.125 \% \\
\text { bupivacaine } \\
\text { and } 0.5 \\
\mu \mathrm{g} / \mathrm{mL} \\
\text { sufentanil } \\
\text { mixture, } \\
\text { discontinued } \\
\text { on the third } \\
\text { postoperative } \\
\text { day after no } \\
\text { dose was } \\
\text { necessary for } \\
\text { at least } 4 \\
\text { hours. }\end{array}$ & $\begin{array}{l}\text { PCA } \\
\text { morphine } 1.5 \\
\text { mg boluses } \\
\text { with 8-minute } \\
\text { lockout. }\end{array}$ & $\begin{array}{l}\text { 1. } \begin{array}{l}\text { Postoperative } \\
\text { pain and side } \\
\text { effects } \\
\text { (pruritis, } \\
\text { vomiting, } \\
\text { sedation) } \\
\text { 2. Postoperative } \\
\text { delirium } \\
\text { 3. Respiratory, } \\
\text { hemodynamic, } \\
\text { and motor } \\
\text { blockade } \\
\text { complications }\end{array}\end{array}$ & $\begin{array}{l}\text { Total of } 108 \\
\text { patients identified; } \\
64 \text { patients } \\
\text { completed the } \\
\text { study. } \\
\text { 1. PCEA } \\
\text { provided } \\
\text { significantly } \\
\text { better pain } \\
\text { relief than } \\
\text { PCA. } \\
\text { 2. Frequency of } \\
\text { postop } \\
\text { delirium was } \\
\text { similar } \\
\text { between } \\
\text { groups. } \\
\text { 3. Frequency and } \\
\text { type of } \\
\text { pulmonary } \\
\text { complications } \\
\text { not } \\
\text { significantly } \\
\text { different } \\
\text { between } \\
\text { groups. Five }\end{array}$ & $\begin{array}{l}\text { Small number } \\
\text { of patients in } \\
\text { study prevents } \\
\text { detection of } \\
\text { significant } \\
\text { data. } \\
\text { Definite } \\
\text { conclusions } \\
\text { could not be } \\
\text { drawn } \\
\text { regarding } \\
\text { length of } \\
\text { hospital stay } \\
\text { since } \\
\text { discharge } \\
\text { criteria was } \\
\text { not defined for } \\
\text { study. }\end{array}$ \\
\hline
\end{tabular}




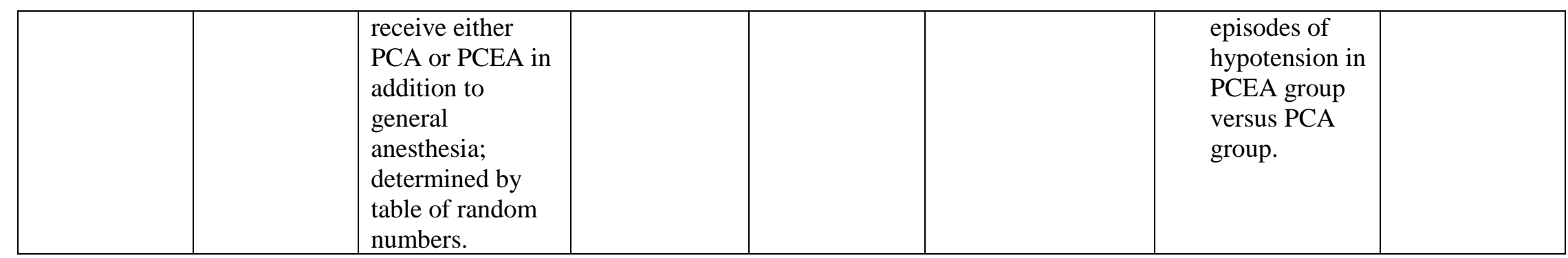


Table D-6: Duch, P. and Moller, M.H. (2015). Epidural analgesia in patients with traumatic rib fractures: A systemic review of randomized controlled trials. Acta Anaesthesiologica Scandinavica, 59, 698-709.

\begin{tabular}{|c|c|c|c|c|c|c|c|}
\hline Purpose & $\begin{array}{l}\text { Study } \\
\text { Desion }\end{array}$ & Sample & Intervention & Comparison & Outcomes & Findings & Limitations \\
\hline $\begin{array}{l}\text { To evaluate } \\
\text { the benefit } \\
\text { and harm of } \\
\text { continuous } \\
\text { epidural } \\
\text { analgesia } \\
\text { when } \\
\text { compared to } \\
\text { other } \\
\text { analgesic } \\
\text { interventions. }\end{array}$ & $\begin{array}{l}\text { Systematic } \\
\text { review }\end{array}$ & $\begin{array}{l}\text { Data collected } \\
\text { from RCTs in } \\
\text { patients with } \\
1+\text { rib } \\
\text { fracture. } \\
\text { Six trials (n= } \\
\text { 223) were } \\
\text { included. }\end{array}$ & $\begin{array}{l}\text { Continuous } \\
\text { epidural } \\
\text { analgesia by } \\
\text { placement of } \\
\text { epidural } \\
\text { catheter. }\end{array}$ & $\begin{array}{ll}\text { 1. } & \begin{array}{l}\text { IV opioid } \\
\text { analgesia by } \\
\text { bolus or } \\
\text { infusion }\end{array} \\
\text { 2. } & \begin{array}{l}\text { Thoracic } \\
\text { paravertebral } \\
\text { blockade }\end{array} \\
\text { 3. } & \begin{array}{l}\text { Interpleural } \\
\text { blockade }\end{array} \\
\text { 4. } & \begin{array}{l}\text { Intercostal } \\
\text { blockade }\end{array}\end{array}$ & 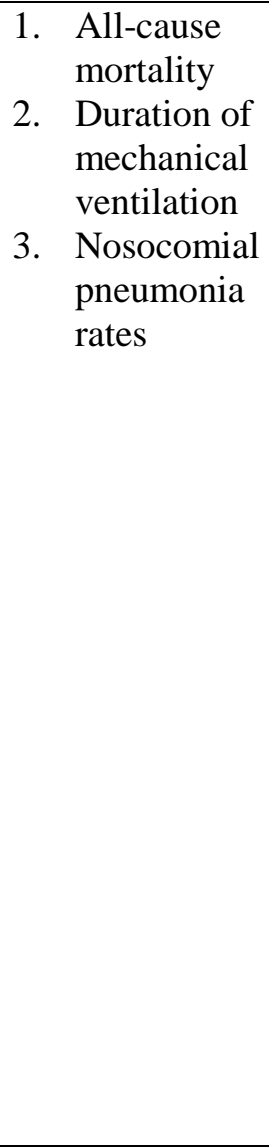 & 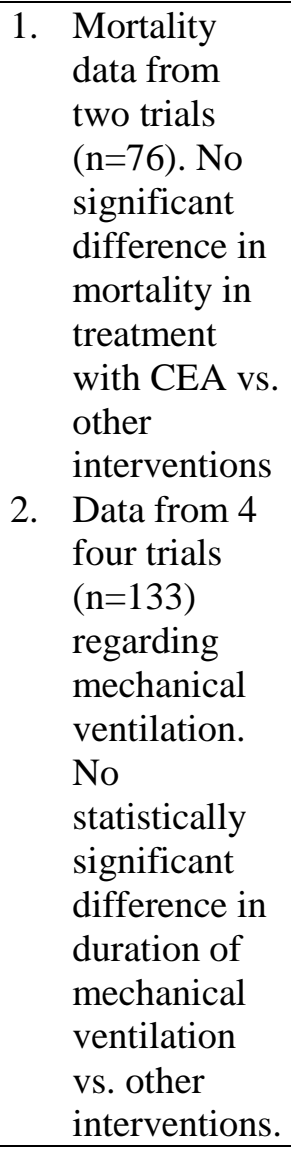 & $\begin{array}{ll}\text { - } & \text { Small sample } \\
\text { size in } \\
\text { measuring } \\
\text { primary } \\
\text { outcome } \\
\text { - } \\
\text { High risk of } \\
\text { bias } \\
\text { - Low quality of } \\
\text { evidence due } \\
\text { to first two } \\
\text { points; more } \\
\text { data is } \\
\text { necessary. }\end{array}$ \\
\hline
\end{tabular}




\begin{tabular}{|l|l|l|l|l|l|}
\hline & & & & & Data \\
regarding \\
pneumonia \\
from three \\
trials \\
(n=108). No \\
statistical \\
significance \\
\end{tabular}




\section{Appendix E: Critical Appraisal Tables}

Table E-1: McKendy, K.M., Lee, L.F., Boulva, K., Deckelbaum, D.L., Mulder, D.S.,

Razek, T.S., \& Grushka, J.R. (2017). Epidural analgesia for traumatic rib

fractures is associated with worse outcomes: a matched analysis. Journal of

Surgical Research, 214, 117-123.

\begin{tabular}{|c|c|c|c|}
\hline A. Are the results of the Trial Valid? & Yes & Can't Tell & No \\
\hline 1. Did the trial address a clearly focused issue? & $\mathrm{X}$ & & \\
\hline $\begin{array}{l}\text { 2. Was the assignment of patients to treatments } \\
\text { randomized? }\end{array}$ & & & $\mathrm{X}$ \\
\hline $\begin{array}{l}\text { 3. Were all of the patients who entered the trial } \\
\text { properly accounted for at its conclusion? }\end{array}$ & $\mathrm{X}$ & & \\
\hline $\begin{array}{l}\text { 4. Were patients, health workers and study } \\
\text { personnel "blind" to treatment? }\end{array}$ & & & $\mathrm{X}$ \\
\hline 5. Were the groups similar at the start of the trial? & $\mathrm{X}$ & & \\
\hline $\begin{array}{l}\text { 6. Aside from the experimental intervention, were } \\
\text { the groups treated equally? }\end{array}$ & $\mathrm{X}$ & & \\
\hline \multicolumn{4}{|l|}{ B. What are the results? } \\
\hline 7. How large was the treatment effect? & \multicolumn{3}{|c|}{$\begin{array}{l}\text { Patients who received epidurals } \\
\text { experienced more respiratory } \\
\text { complications versus those who } \\
\text { did not receive epidurals. There } \\
\text { was no difference in 30-day } \\
\text { mortality. }\end{array}$} \\
\hline $\begin{array}{l}\text { 8. How precise was the estimate of the treatment } \\
\text { effect? }\end{array}$ & \multicolumn{3}{|c|}{$\begin{array}{l}\text { Coarsened exact matching was } \\
\text { used to account for patient-level } \\
\text { differences and to minimize } \\
\text { confounding variables. After } \\
\text { matching was performed } \\
\text { epidural and non-epidural groups } \\
\text { were matched with n=204 to } \\
\text { achieve } 95 \% \text { CI. }\end{array}$} \\
\hline C. Will the results help locally? & Yes & Can't Tell & No \\
\hline $\begin{array}{l}\text { 9. Can the results be applied to the local } \\
\text { population, or in your context? }\end{array}$ & $\mathrm{X}$ & & \\
\hline
\end{tabular}


10. Were all clinically important outcomes considered?

11. Are the benefits worth the harms and costs?

\begin{tabular}{|l|l|l|}
\hline$X$ & & \\
\hline & $X$ & \\
\hline
\end{tabular}


Table E-2: Bulger, E.M., Edwards, T., Klotz, P., \& Jurkovich, G.J. (2004). Epidural analgesia improves outcome after multiple rib fractures. Surgery, 136(2), 426430.

\begin{tabular}{|c|c|c|c|}
\hline A. Are the results of the Trial Valid? & Yes & Can't Tell & No \\
\hline 1. Did the trial address a clearly focused issue? & $\mathrm{X}$ & & \\
\hline $\begin{array}{l}\text { 2. Was the assignment of patients to treatments } \\
\text { randomized? }\end{array}$ & $\mathrm{X}$ & & \\
\hline $\begin{array}{l}\text { 3. Were all of the patients who entered the trial } \\
\text { properly accounted for at its conclusion? }\end{array}$ & $\mathrm{X}$ & & \\
\hline $\begin{array}{l}\text { 4. Were patients, health workers and study } \\
\text { personnel "blind" to treatment? }\end{array}$ & & & $\mathrm{X}$ \\
\hline 5. Were the groups similar at the start of the trial? & $\mathrm{X}$ & & \\
\hline $\begin{array}{l}\text { 6. Aside from the experimental intervention, were } \\
\text { the groups treated equally? }\end{array}$ & $\mathrm{X}$ & & \\
\hline \multicolumn{4}{|l|}{ B. What are the results? } \\
\hline 7. How large was the treatment effect? & \multicolumn{3}{|c|}{$\begin{array}{l}\text { Despite more severe injury, the } \\
\text { epidural group had lower rates of } \\
\text { pneumonia than those who } \\
\text { received IV opioids. }\end{array}$} \\
\hline $\begin{array}{l}\text { 8. How precise was the estimate of the treatment } \\
\text { effect? }\end{array}$ & \multicolumn{3}{|c|}{$\begin{array}{l}\text { Researchers determined the need } \\
\text { for } 22-24 \text { subjects in each group } \\
\text { to achieve a significance } p< \\
0.05 \text {. }\end{array}$} \\
\hline C. Will the results help locally? & Yes & Can't Tell & No \\
\hline $\begin{array}{l}\text { 9. Can the results be applied to the local } \\
\text { population, or in your context? }\end{array}$ & $\mathrm{X}$ & & \\
\hline $\begin{array}{l}\text { 10. Were all clinically important outcomes } \\
\text { considered? }\end{array}$ & $\mathrm{X}$ & & \\
\hline 11. Are the benefits worth the harms and costs? & & $\mathrm{X}$ & \\
\hline
\end{tabular}


Table E-3: Moon, M.R., Luchetter, F.A., Gibson, S.W., Crews, J., Sudarshan, G., Hurst, J.M., ...Fischer, J.E. (1999). Prospective, randomized comparison of epidural versus parenteral opioid analgesia in thoracic trauma. Annals of Surgery, 229(5), 684-692.

\begin{tabular}{|c|c|c|c|}
\hline A. Are the results of the Trial Valid? & Yes & Can't Tell & No \\
\hline 1. Did the trial address a clearly focused issue? & $\mathrm{X}$ & & \\
\hline $\begin{array}{l}\text { 2. Was the assignment of patients to treatments } \\
\text { randomized? }\end{array}$ & $\mathrm{X}$ & & \\
\hline $\begin{array}{l}\text { 3. Were all of the patients who entered the trial } \\
\text { properly accounted for at its conclusion? }\end{array}$ & $\mathrm{X}$ & & \\
\hline $\begin{array}{l}\text { 4. Were patients, health workers and study } \\
\text { personnel "blind" to treatment? }\end{array}$ & & & $\mathrm{X}$ \\
\hline 5. Were the groups similar at the start of the trial? & $\mathrm{X}$ & & \\
\hline $\begin{array}{l}\text { 6. Aside from the experimental intervention, were } \\
\text { the groups treated equally? }\end{array}$ & $\mathrm{X}$ & & \\
\hline \multicolumn{4}{|l|}{ B. What are the results? } \\
\hline 7. How large was the treatment effect? & \multicolumn{3}{|c|}{$\begin{array}{l}\text { There were no significant } \\
\text { differences in clinical } \\
\text { characteristics between the two } \\
\text { study populations. The epidural } \\
\text { group had significantly reduced } \\
\text { pain with chest wall excursion } \\
\text { when compared to PCA group. } \\
\text { Tidal volume and maximal } \\
\text { inspiratory force were also } \\
\text { improved. }\end{array}$} \\
\hline $\begin{array}{l}\text { 8. How precise was the estimate of the treatment } \\
\text { effect? }\end{array}$ & \multicolumn{3}{|c|}{$\begin{array}{l}\text { A probability value of }<0.05 \\
\text { was regarded as significant. No } \\
\text { power analysis for necessary } \\
\text { sample size for significant data } \\
\text { was documented. }\end{array}$} \\
\hline C. Will the results help locally? & Yes & Can't Tell & No \\
\hline $\begin{array}{l}\text { 9. Can the results be applied to the local } \\
\text { population, or in your context? }\end{array}$ & $X$ & & \\
\hline
\end{tabular}


10. Were all clinically important outcomes considered?

11. Are the benefits worth the harms and costs?

\begin{tabular}{|l|l|l|}
\hline$X$ & & \\
\hline & $X$ & \\
\hline
\end{tabular}


Table E-4: Sakura, S., Saito, Y., \& Kosaka, Y. (1996). The effects of epidural anesthesia on ventilatory response to hypercapnia and hypoxia in elderly patients. Anesthesia Analgesia, 82, 306-311.

\begin{tabular}{|c|c|c|c|}
\hline A. Are the results of the Trial Valid? & Yes & Can't Tell & No \\
\hline 1. Did the trial address a clearly focused issue? & $\mathrm{X}$ & & \\
\hline $\begin{array}{l}\text { 2. Was the assignment of patients to treatments } \\
\text { randomized? }\end{array}$ & & & $\mathrm{X}$ \\
\hline $\begin{array}{l}\text { 3. Were all of the patients who entered the trial } \\
\text { properly accounted for at its conclusion? }\end{array}$ & $\mathrm{X}$ & & \\
\hline $\begin{array}{l}\text { 4. Were patients, health workers and study } \\
\text { personnel "blind" to treatment? }\end{array}$ & & & $\mathrm{X}$ \\
\hline 5. Were the groups similar at the start of the trial? & $\mathrm{X}$ & & \\
\hline $\begin{array}{l}\text { 6. Aside from the experimental intervention, were } \\
\text { the groups treated equally? }\end{array}$ & $\mathrm{X}$ & & \\
\hline \multicolumn{4}{|l|}{ B. What are the results? } \\
\hline 7. How large was the treatment effect? & \multicolumn{3}{|c|}{$\begin{array}{l}\text { Neither lumbar nor thoracic } \\
\text { epidural significantly impaired } \\
\text { ventilatory response to } \\
\text { hypercapnia and hypoxia, } \\
\text { despite slight impairment in } \\
\text { resting ventilation with thoracic } \\
\text { epidural. }\end{array}$} \\
\hline $\begin{array}{l}\text { 8. How precise was the estimate of the treatment } \\
\text { effect? }\end{array}$ & \multicolumn{3}{|c|}{$\begin{array}{l}\text { A significance level was } \\
\text { determined to be } p<0.05 \text {. No } \\
\text { power analysis for necessary } \\
\text { sample size for significant } \\
\text { treatment effect was } \\
\text { documented. }\end{array}$} \\
\hline C. Will the results help locally? & Yes & Can't Tell & No \\
\hline $\begin{array}{l}\text { 9. Can the results be applied to the local } \\
\text { population, or in your context? }\end{array}$ & $\mathrm{X}$ & & \\
\hline $\begin{array}{l}\text { 10. Were all clinically important outcomes } \\
\text { considered? }\end{array}$ & $\mathrm{X}$ & & \\
\hline 11. Are the benefits worth the harms and costs? & & $X$ & \\
\hline
\end{tabular}


Table E-5: Mann, C., Pouzeratte, Y., Boccara, G., Peccoux, C., Vergne, C., Brunat, G.,...Colson, P. (2000). Comparison of intravenous or epidural patient-controlled analgesia in the elderly after major abdominal surgery. Anesthesiology, 92(2), 433-44.

\begin{tabular}{|c|c|c|c|}
\hline A. Are the results of the Trial Valid? & Yes & Can't Tell & No \\
\hline 1. Did the trial address a clearly focused issue? & $\mathrm{X}$ & & \\
\hline $\begin{array}{l}\text { 2. Was the assignment of patients to treatments } \\
\text { randomized? }\end{array}$ & $\mathrm{X}$ & & \\
\hline $\begin{array}{l}\text { 3. Were all of the patients who entered the trial } \\
\text { properly accounted for at its conclusion? }\end{array}$ & $\mathrm{X}$ & & \\
\hline $\begin{array}{l}\text { 4. Were patients, health workers and study } \\
\text { personnel "blind" to treatment? }\end{array}$ & & & $\mathrm{X}$ \\
\hline 5. Were the groups similar at the start of the trial? & $\mathrm{X}$ & & \\
\hline $\begin{array}{l}\text { 6. Aside from the experimental intervention, were } \\
\text { the groups treated equally? }\end{array}$ & $\mathrm{X}$ & & \\
\hline \multicolumn{4}{|l|}{ B. What are the results? } \\
\hline 7. How large was the treatment effect? & \multicolumn{3}{|c|}{$\begin{array}{l}\text { Pain relief was better in the } \\
\text { PCEA group during the } 5 \\
\text { postoperative days examined. }\end{array}$} \\
\hline $\begin{array}{l}\text { 8. How precise was the estimate of the treatment } \\
\text { effect? }\end{array}$ & \multicolumn{3}{|c|}{$\begin{array}{l}\text { Power analysis utilizing } \\
\text { postoperative pain during } \\
\text { coughing as a primary outcome } \\
\text { variable determined that a } \\
\text { sample size of } 31 \text { patients per } \\
\text { group was necessary. Each } \\
\text { group had } n=35 \text {. }\end{array}$} \\
\hline C. Will the results help locally? & Yes & Can't Tell & No \\
\hline $\begin{array}{l}\text { 9. Can the results be applied to the local } \\
\text { population, or in your context? }\end{array}$ & $\mathrm{X}$ & & \\
\hline $\begin{array}{l}\text { 10. Were all clinically important outcomes } \\
\text { considered? }\end{array}$ & $\mathrm{X}$ & & \\
\hline 11. Are the benefits worth the harms and costs? & & $\mathrm{X}$ & \\
\hline
\end{tabular}


Table E-6: Duch, P. and Moller, M.H. (2015). Epidural analgesia in patients with traumatic rib fractures: A systemic review of randomized controlled trials. Acta Anaesthesiologica Scandinavica, 59, 698-709.

\begin{tabular}{|c|c|c|c|}
\hline A. Are the results of the review valid? & Yes & Can't Tell & No \\
\hline $\begin{array}{l}\text { 1. Did the review address a clearly focused } \\
\text { question? }\end{array}$ & $\mathrm{X}$ & & \\
\hline $\begin{array}{l}\text { 2. Did the authors look for the right type of } \\
\text { papers? }\end{array}$ & $X$ & & \\
\hline $\begin{array}{l}\text { 3. Do you think all the important, relevant studies } \\
\text { were included? }\end{array}$ & & $\mathrm{X}$ & \\
\hline $\begin{array}{l}\text { 4. Did the review's authors do enough to assess } \\
\text { quality of the included studies? }\end{array}$ & $\mathrm{X}$ & & \\
\hline $\begin{array}{l}\text { 5. If the results of the review have been combined, } \\
\text { was it reasonable to do so? }\end{array}$ & $\mathrm{X}$ & & \\
\hline \multicolumn{4}{|l|}{ B. What are the results? } \\
\hline 6. What are the overall results of the review? & \multicolumn{3}{|c|}{$\begin{array}{l}\text { No statistically significant } \\
\text { evidence for or against utilizing } \\
\text { CEA versus other analgesic } \\
\text { interventions. }\end{array}$} \\
\hline 7. How precise are the results? & \multicolumn{3}{|c|}{$\begin{array}{l}\text { High risk of bias of studies } \\
\text { yielded imprecise data which } \\
\text { was difficult to make } \\
\text { recommendations from. }\end{array}$} \\
\hline C. Will the results help locally? & Yes & Can't Tell & No \\
\hline $\begin{array}{l}\text { 8. Can the results be applied to the local } \\
\text { population? }\end{array}$ & $\mathrm{X}$ & & \\
\hline 9. Were all important outcomes considered? & $\mathrm{X}$ & & \\
\hline 10. Are the benefits worth the harms and costs? & & $\mathrm{X}$ & \\
\hline
\end{tabular}


Appendix F: Cross Study Analysis

\begin{tabular}{|c|c|c|c|c|}
\hline $\begin{array}{l}\text { Author, } \\
\text { Year }\end{array}$ & $\begin{array}{l}\text { Average Age } \\
\text { of Population }\end{array}$ & $\begin{array}{c}\text { Epidural - effect } \\
\text { on pneumonia } \\
\text { rates }\end{array}$ & $\begin{array}{l}\text { Epidural - } \\
\text { effect on } \\
\text { respiratory } \\
\text { failure }\end{array}$ & $\begin{array}{c}\text { Epidural - } \\
\text { effect on } \\
\text { mortality rate }\end{array}$ \\
\hline $\begin{array}{l}\text { McKendy, } \\
\text { et al., } 2017\end{array}$ & $\begin{array}{l}\text { Mean age of } \\
\text { all included } \\
\text { patients: } 54.2 \\
\text { years }\end{array}$ & $\begin{array}{l}9 \% \text { versus } 5 \% \text { in } \\
\text { non-epidural } \\
\text { group when } \\
\text { examined in a } \\
\text { matched cohort } \\
\text { (n=202 for each } \\
\text { group) ( } \mathrm{p}=0.073)\end{array}$ & $\begin{array}{l}\text { In matched } \\
\text { analysis, both } \\
\text { groups reports } \\
2 \% \text { respiratory } \\
\text { failure } \\
(\mathrm{p}=0.703)\end{array}$ & $\begin{array}{l}5 \% \text { in epidural } \\
\text { group versus } 2 \% \\
\text { in non-epidural } \\
\text { group }(\mathrm{p}=0.159)\end{array}$ \\
\hline $\begin{array}{l}\text { Duch \& } \\
\text { Moller, } \\
2015\end{array}$ & $\begin{array}{l}\text { All studies: } \\
>18 \text { years old }\end{array}$ & $\begin{array}{l}\text { Of three trials that } \\
\text { reported data on } \\
\text { pneumonia rates } \\
(\mathrm{n}=108) \text {, there } \\
\text { was no } \\
\text { statistically } \\
\text { significant data } \\
\text { showing a } \\
\text { difference } \\
\text { between epidural } \\
\text { use and } \\
\text { conventional } \\
\text { treatment ( } \mathrm{p}= \\
0.13) .\end{array}$ & $\begin{array}{l}\text { Four trials } \\
\text { reported on } \\
\text { mechanical } \\
\text { ventilation } \\
\text { duration ( } \mathrm{n}= \\
\text { 133). There was } \\
\text { no statistical } \\
\text { significance } \\
\text { determined } \\
\text { between } \\
\text { continuous } \\
\text { epidural } \\
\text { analgesia and } \\
\text { conventional } \\
\text { treatment ( } \mathrm{p}= \\
0.09 \text { ). }\end{array}$ & $\begin{array}{l}\text { Two trials } \\
\text { reported on all- } \\
\text { cause mortality } \\
(\mathrm{n}=76) \text {. No } \\
\text { statistical } \\
\text { significance was } \\
\text { shown between } \\
\text { epidural use and } \\
\text { other analgesic } \\
\text { interventions ( } \mathrm{p} \\
=0.51) \text {. }\end{array}$ \\
\hline $\begin{array}{l}\text { Bulger, et } \\
\text { al., } 2004\end{array}$ & $\begin{array}{l}\text { Epidural: } 49 \pm \\
18 \text { years } \\
\underline{\text { Opioids: }} 46 \pm \\
16 \text { years }\end{array}$ & $\begin{array}{l}18 \% \text { in epidural } \\
\text { group versus } 38 \% \\
\text { in systemic opioid } \\
\text { group }(95 \% \mathrm{CI}, \mathrm{P} \\
=0.05) .\end{array}$ & $\begin{array}{l}\text { Mean of } 7.6 \\
\text { days versus } 9.1 \\
\text { days for } \\
\text { systemic opioid } \\
\text { group }(95 \% \mathrm{CI}, \\
\mathrm{P}=0.09)\end{array}$ & $\begin{array}{l}\text { No statistical } \\
\text { difference } \\
\text { between groups. } \\
\text { Unadjusted } \\
\text { parameters } \\
\text { showed } 9 \% \\
\text { mortality in } \\
\text { epidural group } \\
\text { versus } 4.2 \% \text { in } \\
\text { opioid group (P } \\
=0.5 \text { ) }\end{array}$ \\
\hline $\begin{array}{l}\text { Mann, et } \\
\text { al., } 2000\end{array}$ & $\begin{array}{l}\frac{\text { Patient- }}{\text { controlled }} \\
\underline{\text { epidural }} \\
\underline{\text { analgesia }}\end{array}$ & $\begin{array}{l}\text { This study did not } \\
\text { investigate rates } \\
\text { of pneumonia. }\end{array}$ & $\begin{array}{l}\text { Frequency and } \\
\text { type of } \\
\text { pulmonary } \\
\text { complications } \\
\text { were not } \\
\text { statistically }\end{array}$ & $\begin{array}{l}\text { All-cause } \\
\text { mortality was } \\
\text { not investigated } \\
\text { in this study. }\end{array}$ \\
\hline
\end{tabular}




\begin{tabular}{|c|c|c|c|c|}
\hline & $\begin{array}{l}\text { (PCEA): } 76.1 \\
\pm 5.6 \text { years } \\
\text { Patient- } \\
\frac{\text { controlled }}{\text { analgesia }} \\
\frac{(\text { PCA }): 76.8 \pm}{4.7}:\end{array}$ & & $\begin{array}{l}\text { significant } \\
\text { between the two } \\
\text { groups ( } 3 \% \text { in } \\
\text { each group). }\end{array}$ & \\
\hline $\begin{array}{l}\text { Moon, et } \\
\text { al., } 1999\end{array}$ & $\begin{array}{l}\text { Epidural: } \\
\text { Average age } \\
37(\mathrm{n}=13) \\
\text { PCA: Average } \\
\text { age } 40(\mathrm{n}= \\
11)\end{array}$ & $\begin{array}{l}\text { This study did not } \\
\text { specifically } \\
\text { address } \\
\text { pneumonia rates, } \\
\text { and rather } \\
\text { inferred the effect } \\
\text { of epidural use } \\
\text { through effects on } \\
\text { pulmonary } \\
\text { complications. }\end{array}$ & $\begin{array}{l}\text { Patients in the } \\
\text { epidural group } \\
\text { showed a } \\
\text { continued } \\
\text { increase (23\%) } \\
\text { in maximal } \\
\text { inspiratory } \\
\text { force (MIF) } \\
\text { over the course } \\
\text { of the 3-day } \\
\text { study (p < } \\
0.05 \text { ). Those in } \\
\text { the PCA group } \\
\text { had a gradual } \\
\text { decline (13\%) } \\
\text { in MIF. Tidal } \\
\text { volume also } \\
\text { improved in the } \\
\text { epidural group } \\
\text { (by } 45 \% \text { ), and } \\
\text { by day } 3 \\
\text { averaged } 590 \\
\text { mL versus } 327 \\
\text { mL in the PCA } \\
\text { group (p < } \\
0.05 \text { ). }\end{array}$ & $\begin{array}{l}\text { Mortality was } \\
\text { not directly } \\
\text { addressed in this } \\
\text { study, and rather } \\
\text { inferred through } \\
\text { results related to } \\
\text { pulmonary } \\
\text { complications. }\end{array}$ \\
\hline $\begin{array}{l}\text { Sakura, et } \\
\text { al., } 1996\end{array}$ & $\begin{array}{l}\text { Lumbar } \\
\text { Epidural: } \\
5 \text { years } \\
\text { Thoracic } \\
\text { Epidural: } \\
61 \pm \text { years }\end{array}$ & $\begin{array}{l}\text { Rates of } \\
\text { pneumonia were } \\
\text { not addressed in } \\
\text { this study. }\end{array}$ & $\begin{array}{l}\text { Minute } \\
\text { ventilation } \\
\text { decreased by } \\
6 \% \text { in the } \\
\text { lumbar group } \\
\text { and } 13 \% \text { in } \\
\text { epidural group. } \\
\text { Respiratory } \\
\text { failure and } \\
\text { mechanical } \\
\text { ventilation was } \\
\text { not addressed. }\end{array}$ & $\begin{array}{l}\text { Mortality was } \\
\text { not investigated } \\
\text { in this study. }\end{array}$ \\
\hline
\end{tabular}

